\title{
Distinct K Currents Result in Physiologically Distinct Cell Types in the Inferior Colliculus of the Rat
}

\author{
Shobhana Sivaramakrishnan and Douglas L. Oliver \\ Department of Neuroscience, University of Connecticut Health Center, Farmington, Connecticut 06030-3401
}

The inferior colliculus (IC) processes auditory information ascending from the brainstem. The response of the IC to this information and its ability to transform it is partly determined by the types of ionic currents that generate the intrinsic discharge patterns of IC neurons and their susceptibility to changes in the external environment. We have used whole-cell patch-clamp techniques on IC neurons in rat brain slices to characterize the potassium currents present and to correlate them with the firing patterns observed. Neurons in the IC can be classified into six physiologically distinct cell types. Each of these cell types has a firing pattern that is generated by a unique potassium current and set of cellular parameters. Sustained-regular cells show mainly delayed rectifier $\mathrm{K}^{+}$channels. Onset cells have a unique high-threshold tetraethylammonium-sensitive $\mathrm{K}^{+}$current. Pause-build cells have an $\mathrm{A}$ current. Rebound-regular cells have calcium-dependent rebound depolarizations. Rebound-adapting cells have both an apaminsensitive calcium-dependent $\mathrm{K}^{+}$current and a calciumdependent rebound depolarization. Transient-rebound cells have a charybdotoxin-sensitive calcium-dependent $\mathrm{K}^{+}$current and a calcium-dependent rebound.

Our data suggest that there would be similarities as well as differences among IC neurons in their responses to excitatory or inhibitory inputs. Furthermore, some cells are likely to show little or no plasticity and behave as simple relays of temporal and intensity information, whereas others are likely to transform their inputs.

Key words: inferior colliculus; adaptation; rebound firing; high-threshold potassium current; $\mathrm{Ca}^{2+}$-dependent $\mathrm{K}^{+}$current; charybdotoxin; apamin; A-current; $\mathrm{Ca}^{2+}$ spikes
The inferior colliculus (IC) receives information about sound from the lower brainstem and sends it to the auditory cortex via the medial geniculate body. Neurons in the IC are faced with integrating information from numerous inhibitory synapses, often with latencies that are shorter than the excitatory synapses (Kuwada et al., 1997). The ability of the IC to integrate these inputs will be determined, in part, by the physiological state of each IC neuron at the time it receives synaptic input. This physiological state, and the resultant extent to which the IC modifies the synaptic information it receives, will be shaped by its discharge pattern and the modifiability of the ionic currents that underlie its firing.

The ability of IC neurons to integrate synaptic information will depend on the nature of the voltage- and calcium $\left(\mathrm{Ca}^{2+}\right)$-gated potassium $\left(\mathrm{K}^{+}\right)$channels that underlie its discharge pattern. For example, $\mathrm{Ca}^{2+}$-dependent $\mathrm{K}^{+}$currents have been hypothesized to contribute to the adaptation exhibited by some IC neurons (Cai et al., 1998). This adaptation may be the means by which the IC codes interaural phase modulation (McAlpine et al., 2000). Adaptation is an intrinsic feature of some IC neurons (Wagner, 1994; Peruzzi et al. 2000), but the underlying ionic mechanisms have not been explored. Other IC neurons exhibit a pause in the onset of sustained firing (pause-build firing pattern) (Kuwada et al., 1984, 1997; Rees et al., 1997; Peruzzi et al. 2000), which may be evoked by either synaptic inhibition or the intrinsic afterhyperpolarization of the cell. An A-type K current has been shown to

Received Nov. 20, 2000; revised Jan. 16, 2001; accepted Jan. 26, 2001.

This work was funded by National Institutes of Health Grant RO1-DC00189 to D.L.O. We thank Dr. S. Kuwada for valuable discussions during this work and for comments on this manuscript, two anonymous reviewers for helpful suggestions, and D. Bishop for technical assistance.

Correspondence should be addressed to either author at the above address. E-mail: doliver@neuron.uchc.edu or shobhana@neuron.uchc.edu.

Copyright (C) 2001 Society for Neuroscience 0270-6474/01/212861-17\$15.00/0 underlie similar pause-build firing patterns in other systems (Connor and Stevens, 1971a,b; Neher, 1971; Kim et al., 1994; Kanold and Manis, 1999), but the presence of A-currents has not been shown in the IC. Onset and regularly firing sustained neurons are also intrinsically exhibited firing patterns in the IC (Peruzzi et al., 2000), and these cells may use other types of ionic conductances, not yet identified, to integrate synaptic information.

In this study, we have used the whole-cell patch-clamp technique (Hamill et al., 1981) to examine the ionic currents that trigger the firing patterns of IC neurons. Based on the firing patterns in response to depolarizing and hyperpolarizing currents and the types of $\mathrm{K}^{+}$currents present, we find that there are six distinct cell types in the IC. Our results suggest that these physiologically defined cell types will integrate incoming excitatory and inhibitory synaptic information differently. Our results also suggest that some neurons in the IC are capable of modifying the information they receive, whereas others are likely to relay this information unmodified to their targets.

Parts of this work have been published previously in abstract form (Sivaramakrishnan and Oliver, 1998).

\section{MATERIALS AND METHODS}

Long-Evans rats, 8- to 17-d-old, were anesthetized with a mixture of ketamine-xylazine and then decapitated. The brain was removed and placed in warm, oxygenated saline $\left(35^{\circ} \mathrm{C}\right)$, and a block containing the IC was glued onto the stage of a vibratome (Ted Pella Inc., Redding, CA). Transverse brain slices, 300- $\mu \mathrm{m}$-thick, were made through the IC (Fig. 1) and incubated at $35^{\circ} \mathrm{C}$ in saline oxygenated with a $95 \% \quad \mathrm{O}_{2}-5 \% \mathrm{CO}_{2}$ mixture for $1 \mathrm{hr}$ before recording. For recording, individual slices were transferred to a Peltier-driven slice chamber (model PSMI; Medical Systems Corp., Greenvale, NY), which was fixed to the stage of an upright microscope (Axioskop; Zeiss, Oberkochen, Germany) fitted with a water immersion objective $(40 \times, 0.75$ numerical aperture) and differential interference optics. Experiments were performed at $35^{\circ} \mathrm{C}$, and the 


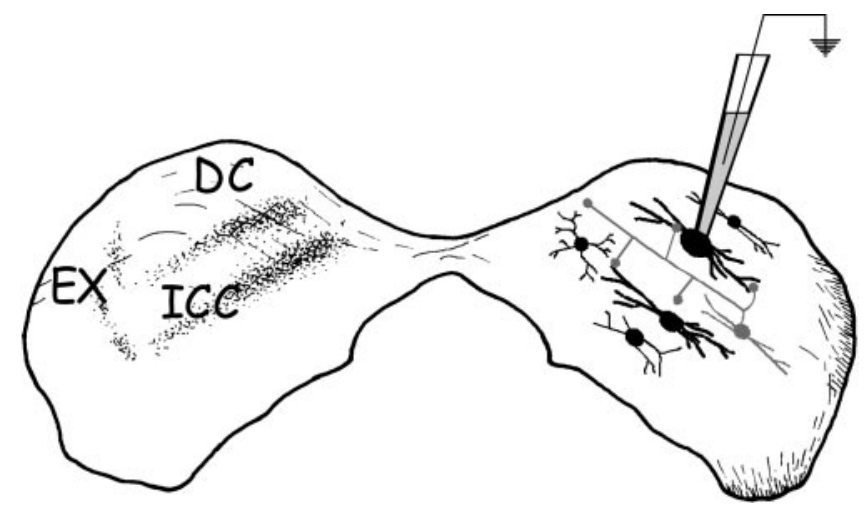

Figure 1. Schematic drawing of a transverse brain slice through the inferior colliculus of the rat. EX, External cortex; $D C$, dorsal cortex; ICC, central nucleus. Cells are drawn as disk-shaped in the central nucleus, oriented with their dendritic trees parallel to the laminae (adapted from Saldana and Merchan, 1992).

slice was continuously perfused with oxygenated saline (in mM: 120 $\mathrm{NaCl}, 5 \mathrm{KCl}, 2.4 \mathrm{CaCl}_{2}, 1.3 \mathrm{MgSO}_{4}, 1 \mathrm{KH}_{2} \mathrm{PO}_{4}, 10 \mathrm{NaHCO}_{3}$, and 25 glucose, $\mathrm{pH}$ 7.3). Whole-cell patch-clamp techniques were used in current-clamp and voltage-clamp modes on the same cell to identify the voltage-dependent currents present and to examine their contribution to the firing pattern of the cell. Recordings were made using patch pipettes of 5-7 M $\Omega$ resistance made from borosilicate glass $(1.5 \mathrm{~mm}$ outer diameter; Kimax). Pipettes were filled with a solution containing (in $\mathrm{mM}$ ): $120 \mathrm{~K}$-gluconate, $5 \mathrm{NaCl}, 11 \mathrm{EGTA}, 1 \mathrm{CaCl}_{2}, 0.3 \mathrm{Na}-\mathrm{GTP}$, and 10 HEPES, $\mathrm{pH}$ 7.3. In some experiments, the internal solution contained 0.6 mM EGTA and $10 \mathrm{~mm} \mathrm{KCl}$ instead of $11 \mathrm{~mm}$ EGTA and $1 \mathrm{~mm} \mathrm{CaCl}_{2}$. Inorganic and organic channel blockers were obtained from Sigma (St. Louis, MO) and Alomone Labs (Jerusalem, Israel). The ion channel blockers used were 4-aminopyridine (4-AP), tetraethylammonium chloride (TEA-Cl), tetrodotoxin (TTX), charybdotoxin (CTX), and apamin.

An EPC-8 amplifier (Heka Elektroniks/InstruTech Corporation, Lambrecht/Pfalz, Germany) was used for both current- and voltageclamp recordings, and pClamp software (Axon Instruments, Foster City, CA) was used for data collection and analyses. Series resistances were generally $15-25 \mathrm{M} \Omega$ and were compensated by $80-85 \%$. Recordings made with lower compensation were not included in the analyses. Data were filtered at $5 \mathrm{kHz}$ during acquisition.

Location of IC neurons. In this study, data are presented only from neurons in the central nucleus of the IC. In the transverse plane of section used, the central nucleus was a small region located approximately in the center of the slice (Fig. 1). To avoid inadvertent recordings from the external nucleus and dorsal cortex, the most caudal and rostral slices through the IC, in which the central nucleus is missing, were discarded. Under Nomarski optics, the central nucleus could be distinguished from the dorsal cortex and external nucleus by its greater opacity. In addition, neurons in the external nucleus had very large cell bodies and dendrites oriented parallel to the lateral edge of the brain slice, whereas neurons in the dorsal cortex almost always exhibited $\mathrm{Ca}^{2+}$-dependent subthreshold potentials in response to depolarizing current injection, as first shown by Smith (1992).

Effectiveness of the voltage-clamp in IC neurons. Neurons in the central nucleus of the IC have 10 - to $20-\mu \mathrm{m}$-diameter soma and long dendrites that extend up to $300 \mu \mathrm{m}$ away from the cell body and are unlikely to be effectively space-clamped from a point source such as an electrode in the cell body. Despite this drawback, we chose to use intact neurons in brain slices rather than dissociated cell bodies to retain the full complement of ion channels and firing patterns. The area of membrane affected by the patch electrode could be estimated by the magnitude of the cell capacitance. The mean capacitance, $C_{\mathrm{m}}$, of IC neurons was $140 \pm 35 \mathrm{pF}(n=$ 62), which corresponds to a cell diameter, d, of $60 \mu \mathrm{m}$ and a spherical surface area of $14,000 \mu \mathrm{m}^{2}\left(C_{\mathrm{m}}=\pi \mathrm{d}^{2} / 100\right)$ (Sakmann and Neher, 1984). The actual measured diameter of cell bodies of IC neurons was, however, $15 \mu \mathrm{m}$, corresponding to an area of $\sim 600 \mu \mathrm{m}^{2}$. The additional 13,400 $\mu \mathrm{m}^{2}$ suggested that the patch electrode was able to measure currents from the cell body, as well as part of the dendritic tree and axon. This extensive area, however, resulted in incomplete spatial control of voltage over the whole cell. $\mathrm{Na}^{+}$currents remained unclamped in every cell from which recordings were made. $\mathrm{K}^{+}$currents, on the other hand, were clamped more effectively, as indicated by their low thresholds of activation and rapid rise times. This suggested that the majority of the measurable $\mathrm{K}^{+}$current flowed through channels in the cell body or proximal parts of the dendrites and axon. Although it was not possible to quantify the activation kinetics of the various $\mathrm{K}^{+}$currents present because of the lack of spatial control, we could identify them by pharmacological means and correlate their activation with a particular firing pattern.

\section{RESULTS \\ Responses to depolarizing current: sustained firing in IC neurons}

\section{Sustained-regular firing}

Sustained firing was the most prevalent firing pattern in the IC ( 73 of 104 cells), as also shown by Peruzzi et al. (2000). Of these 73 cells, 44 showed sustained firing with constant interspike intervals (sustained-regular firing). This regularity was observed at all current levels that generated sustained firing (Fig. 2A). Spike frequency increased linearly until a membrane potential of approximately $-25 \mathrm{mV}$ (Fig. $2 B$ ), after which depolarization block was observed. Neither low- $\mathrm{Ca}^{2+}$ saline nor externally applied apamin $\left(5 \mu \mathrm{M}\right.$, a blocker of the slow $\mathrm{Ca}^{2+}$-activated $\mathrm{K}^{+}$ conductance) or charybdotoxin $\left(100 \mathrm{~nm}\right.$, which blocks the $\mathrm{B}_{\mathrm{K}}$ type of $\mathrm{Ca}^{2+}$-activated $\mathrm{K}^{+}$current) (for review, see Sah, 1996) affected the frequency or pattern of firing during a long current step $(n=4)$ (Fig. $2 C$ ), confirming the absence of $\mathrm{Ca}^{2+}$-activated $\mathrm{K}^{+}$ conductances in the soma of cells with a regular firing pattern. Application of $2 \mathrm{~mm}$ 4-AP, however, slowed the repolarizing phase of the action potential and increased its duration almost threefold, from $1.1 \pm 0.4 \mathrm{msec}$ (measured at half the peak height) to $3.8 \pm 0.6 \mathrm{msec}(n=5)$ (Fig. $2 D)$ but did not significantly affect the afterhyperpolarization that accompanied single action potentials. For the cell shown in Figure 2D, the afterhyperpolarization $20 \mathrm{msec}$ after the stimulus artifact was $2.6 \mathrm{msec}$ in control condi-

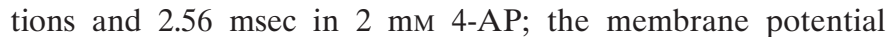
returned to baseline $38 \mathrm{msec}$ after the stimulus artifact in both control conditions and in 4-AP. The slow afterhyperpolarization after sustained firing was also unaffected by apamin and charybdotoxin ( $n=4$; data not shown).

\section{$K$ currents in sustained-regular cells}

Non-inactivating delayed-rectifying $\mathrm{K}^{+}$currents may be sufficient to generate a nonadapting sustained firing pattern, that is, one with a constant interspike interval (Hodgkin and Huxley, 1952). We therefore examined these neurons for the presence of delayed-rectifying currents, as well as other $\mathrm{K}^{+}$currents. Outward $\mathrm{K}^{+}$currents were recorded under voltage-clamp in the presence of TTX (Fig. 3A). These currents showed very slight, slow inactivation during the $300 \mathrm{msec}$ voltage step (more noticeable in Fig. $3 C$ ). Reducing the external $\mathrm{Ca}^{2+}$ from the normal concentration of 2.4 to $0.1 \mathrm{~mm}$ had no effect on the amplitudes or activation threshold of the steady-state or instantaneous magnitudes of the outward current $(n=4)$ (the instantaneous component for one cell is shown in Fig. $3 B$ ). In both normal and low $\mathrm{Ca}^{2+}$, the $\mathrm{K}^{+}$current activated at approximately $-40 \mathrm{mV}$ and increased linearly with voltage.

To determine whether high- and low-threshold delayed rectifier $\mathrm{K}^{+}$currents contributed to the outward current, we used two different concentrations each of 4-AP and of TEA-Cl. Lower concentrations of 4 -AP $(0.2 \mathrm{~mm})$ or TEA-Cl $(0.2 \mathrm{~mm})$ block high-threshold $\mathrm{K}^{+}$currents that flow through Kv3.1 channels (Brew and Forsythe, 1995; Wang et al., 1998), whereas higher 


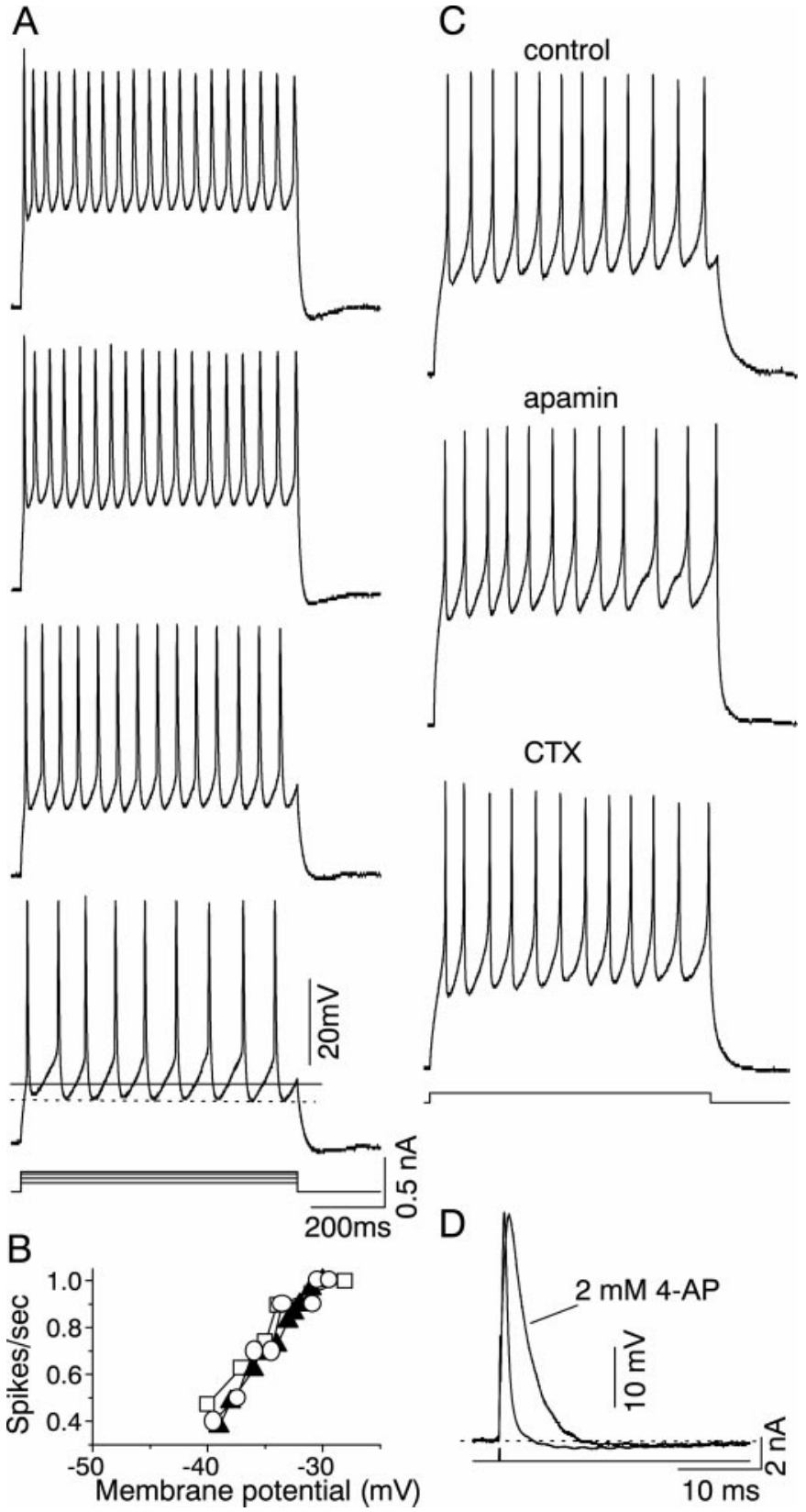

Figure 2. Effect of $\mathrm{K}^{+}$channel blockers on sustained-regular firing. $A$, Current-clamp records of sustained-regular firing at increasing levels of current injection (the injected current strength increases from the bottom to the top). The membrane potential for each current step was assumed to be the baseline potential (indicated by the solid line in the bottom voltage trace), which would have resulted in the absence of firing. The dotted line on the same trace indicates the level of depolarization that results from the afterhyperpolarization that follows each action potential, which is $\sim 5$ $\mathrm{mV}$. $B$, Plot of firing frequency as a function of the membrane potential for three different sustained-regular cells. The membrane potential plotted on the $x$-axis corresponds to the baseline membrane potential, as characterized in $A$; however, results are similar if the dashed line is used, because there is little accumulation of afterhyperpolarization during the maintained current pulse. Because the absolute firing frequency varies between different cells, the firing frequency for each cell has been normalized to its maximum frequency. $C$, Application of $5 \mu \mathrm{M}$ apamin and $100 \mathrm{~nm}$ charybdotoxin to cells with a sustained pattern. Apamin application and washout were followed by CTX application and washout (data not shown) to the same cell. $D$, Action potentials recorded in the soma of a sustained-regular cell in normal saline with and without $2 \mathrm{~mm}$ 4-AP. Action potentials were evoked with single $0.2 \mathrm{msec}$ current pulses injected into the soma. The duration of the action potential, measured at half the peak, is $1.2 \mathrm{msec}$ without $4-\mathrm{AP}$ and $6 \mathrm{msec}$ in 4 -AP.
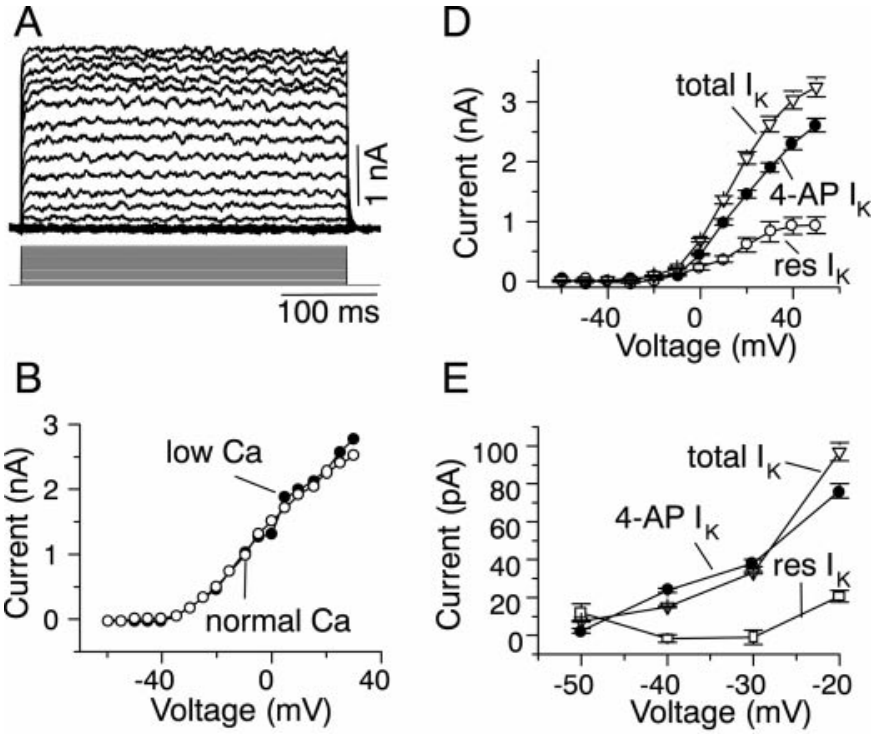

$E$
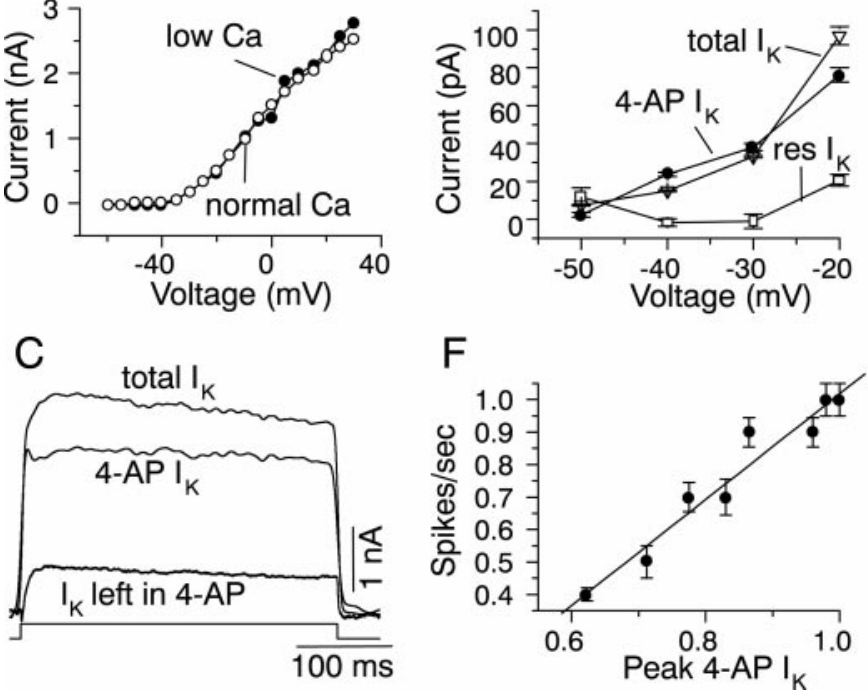

Figure 3. $\mathrm{K}^{+}$currents in a sustained-regular cell. A, Voltage-clamp recordings of outward currents in a sustained-regular cell in the presence of $2 \mu \mathrm{M}$ TTX. The cell was held at $-60 \mathrm{mV}$ and stepped to $+40 \mathrm{mV}$ in 5 $\mathrm{mV}$ increments. $B$, Instantaneous $\mathrm{K}^{+}$current amplitudes, measured 50 msec after the start of the voltage step in external saline containing normal $\mathrm{Ca}^{2+}(2.4 \mathrm{mM})$ and low $\mathrm{Ca}^{2+}(0.1 \mathrm{mM}) . C, \mathrm{~K}^{+}$currents, recorded in TTX, with and without the addition of $2 \mathrm{~mm}$ 4-AP. Top trace, Total current in TTX; bottom trace, current remaining after addition of $2 \mathrm{mM}$ 4-AP; middle trace, the 4-AP-sensitive current obtained by subtracting the bottom trace from the top trace. $D$, Plot of the steady-state $\mathrm{K}^{+}$current amplitude as a function of the voltage level during voltage-clamp recordings. Mean \pm SEM of seven cells. $E, \mathrm{~K}^{+}$currents plotted for a voltage range corresponding to the dynamic range of the cell. 4-AP $I_{K}$, 4-APsensitive $\mathrm{K}^{+}$current; res $I_{K}$, current insensitive to 4-AP. Mean \pm SEM of the same seven cells shown in $D$. $F$, Plot of the firing frequency as a function of the peak amplitude of the 4-AP-sensitive $\mathrm{K}^{+}$current, both being recorded at similar membrane potentials, corresponding to the dynamic range of the cell.

concentrations of these $\mathrm{K}^{+}$channel blockers $(2 \mathrm{~mm}$ 4-AP and 10 mM TEA-Cl) affect several different types of delayed rectifier and other $\mathrm{K}^{+}$channels (Chandy and Guttman, 1995). In IC neurons with a sustained-regular firing pattern, neither $0.2 \mathrm{~mm} 4-\mathrm{AP}(n=$ 7) nor $0.2 \mathrm{~mm}$ TEA-Cl $(n=3)$ had a measurable effect on the total $\mathrm{K}^{+}$current (data not shown), suggesting that high-threshold currents flowing through Kv3.1 channels were absent in these cells. Increasing the concentration of 4-AP to $2 \mathrm{~mm}$ reduced the total outward current by $86 \pm 7.6 \%$, leaving $14 \%$ of a 4 -APinsensitive current $(n=7)$ (Fig. $3 C, D)$. The current remaining in $2 \mathrm{~mm} 4$-AP was completely blocked by $10 \mathrm{~mm}$ TEA-Cl $(n=5)$. The 4-AP-sensitive $\mathrm{K}^{+}$current activated at approximately -40 $\mathrm{mV}$, which was similar to the activation voltage of the total $\mathrm{K}^{+}$ current (Fig. 3D,E). The 4-AP-insensitive fraction (Fig. 3E, res $\left.I_{K}\right)$, however, activated at higher voltages, between -20 and -10 $\mathrm{mV}$, in the seven cells examined. The resistance to 4-AP and the 

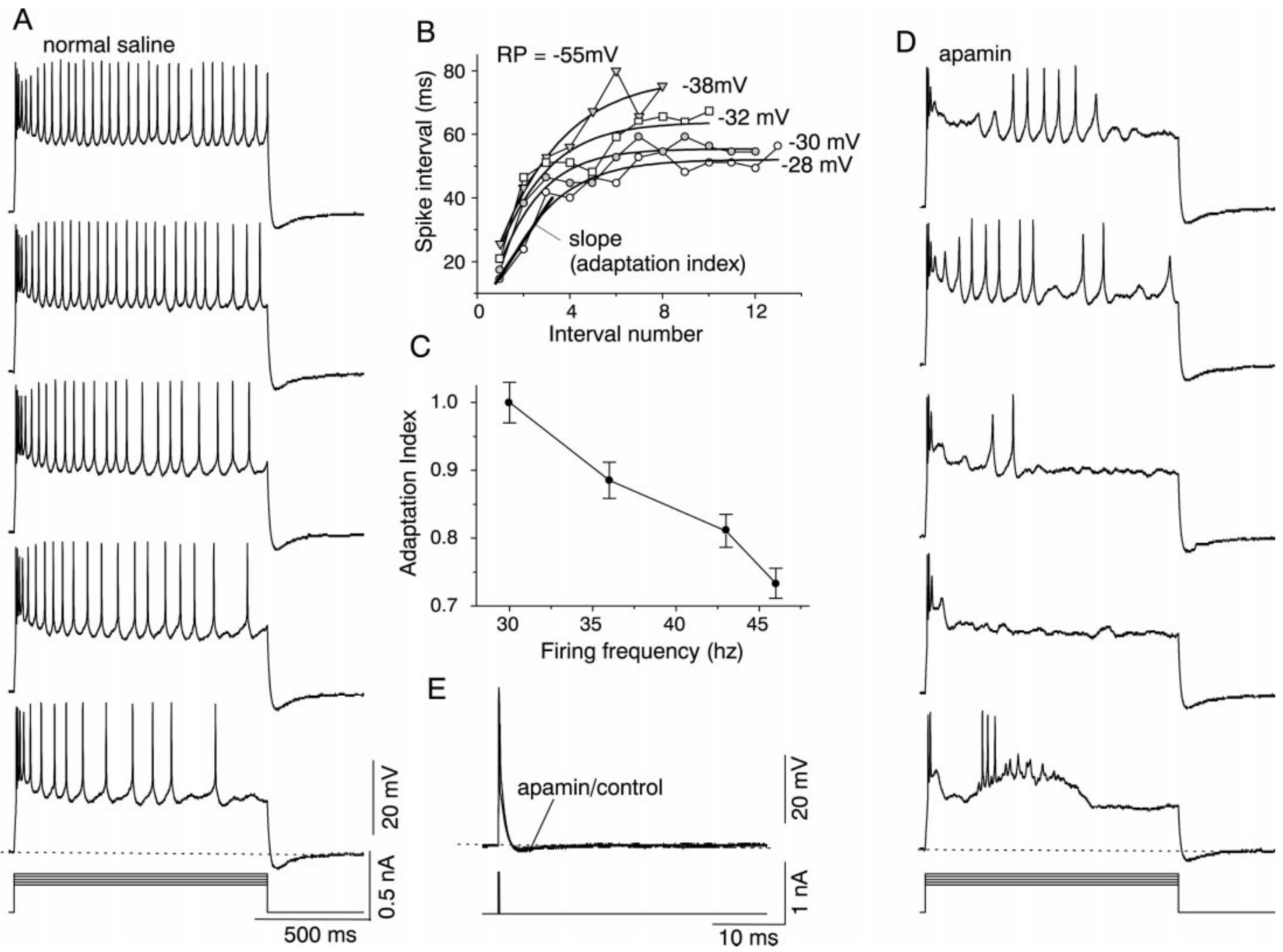

Figure 4. Adaptation during sustained firing and effects of apamin. $A$, Firing patterns in normal saline during 1-sec-long injected current pulses. $B$, Interspike intervals plotted as a function of spike number for the cell in $A$. The slope of the initial part of each curve corresponding to the 1 st through 12th spike is termed the adaptation index at each depolarization. The adaptation index was determined by measuring the interspike interval during the first $300 \mathrm{msec}$, at which the greatest change in interspike interval occurred at all membrane potentials. Abscissa, Interval 1 is the interval between the first two spikes, interval 2 is that between the second and third spike, and so on. $C$, Relationship between adaptation index and firing frequency. Mean \pm SEM are plotted for five cells. $D$, Effect of $5 \mu \mathrm{M}$ apamin on firing in a sustained-adapting cell. Same cell as in $A$. E, Effect of apamin on the afterhyperpolarization that follows a single action potential. Superimposed action potentials evoked in normal saline and in $5 \mu \mathrm{M}$ apamin, by a $0.2 \mathrm{msec}$ current pulse injected into the soma of a sustained-adapting cell.

lack of effect of $0.2 \mathrm{~mm}$ TEA-Cl on $\mathrm{K}^{+}$currents in sustainedregular cells suggests that the high-threshold 4-AP-insensitive fraction is unlikely to be attributable to current flowing through Kv3.1 channels. Instead, the high-threshold of activation could have been attributable to a poor space clamp of the dendritic arbor of the cell or could reflect the actual kinetics of a highthreshold $\mathrm{K}^{+}$current that does not flow through Kv3.1 channels. The total outward $\mathrm{K}^{+}$current was also blocked completely by high concentrations of charybdotoxin ( $600 \mathrm{nM}$ to $1 \mu \mathrm{M} ; n=4$; data not shown), which has been shown to block calcium-independent delayed-rectifying $\mathrm{K}^{+}$currents in other cells (Hartmann et al., 1991; Luneau et al., 1991; Grissmer et al., 1994).

Thus, $\mathrm{K}^{+}$currents in sustained-regularly firing cells are likely to be comprised of delayed rectifiers that are blocked by high concentrations of 4-AP, TEA-Cl, and charybdotoxin and lack components that are sensitive to external $\mathrm{Ca}^{2+}$, low concentrations of TEA-Cl, or blockers of calcium-dependent $\mathrm{K}^{+}$currents.

Because regular firing and changes in firing frequency were observed when the baseline membrane potential fell in the range of -40 and $-25 \mathrm{mV}$ (Fig. $2 B$ ), this voltage range constitutes the dynamic range of regularly firing cells. To determine the contribution of the 4-AP-sensitive $\mathrm{K}^{+}$current to the firing pattern within this voltage range, we examined the relationship between its instantaneous magnitude and the firing frequency, for $\mathrm{K}^{+}$ currents activated by voltage steps in a membrane potential range that corresponded to the baseline membrane potential range of -40 and $-25 \mathrm{mV}$. This baseline potential is similar to that observed in the presence of tetrodotoxin (Peruzzi et al., 2000), indicating that long-lasting action potential-derived active conductances do not contribute to the baseline membrane potential at any current level. Because of inadequate space clamp of membrane voltage, the most marked activation of the 4-AP-sensitive $\mathrm{K}^{+}$current was observed only at membrane voltages more depolarized than $-20 \mathrm{mV}$; however, slight activation was observed at $-40 \mathrm{mV}$ (Fig. $3 E$, filled circles). The relationship between firing frequency and the peak instantaneous 4 -AP-sensitive $\mathrm{K}^{+}$current 


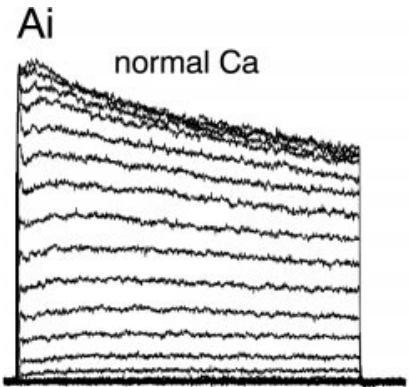

Ci
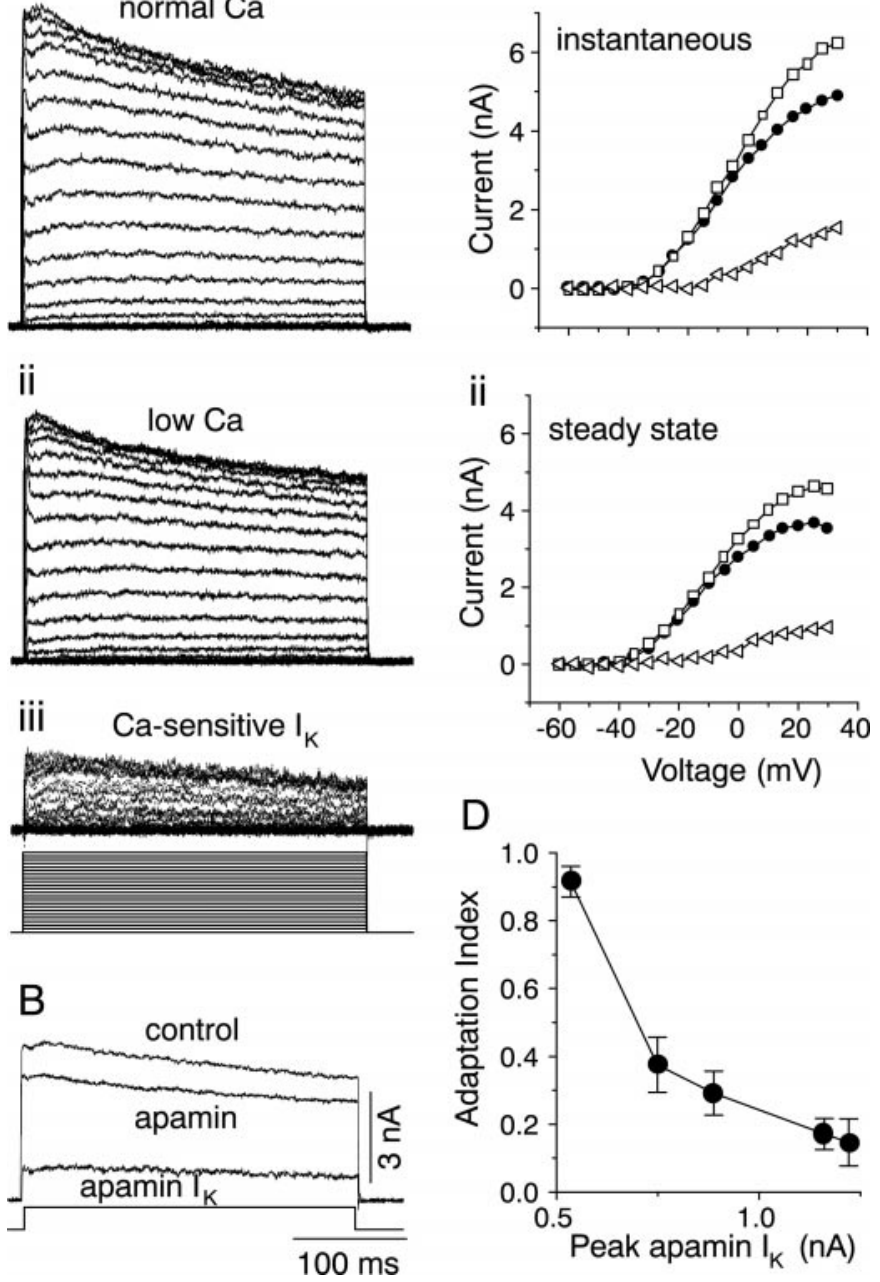

Figure 5. Apamin-sensitive $\mathrm{Ca}^{2+}$-dependent $\mathrm{K}^{+}$currents in cells with a sustained-adapting discharge pattern. $A, \mathrm{~K}^{+}$currents measured in $2 \mu \mathrm{M}$ TTX in normal, $2.4 \mathrm{mM} \mathrm{Ca}^{2+}(i)$, and $0.1 \mathrm{mM} \mathrm{Ca}^{2+}$ (ii). Aiii, The $\mathrm{Ca}^{2+}$-dependent current is obtained by subtracting $i i$ from $i$. The cell was depolarized from a holding potential of -60 to $+50 \mathrm{mV}$ in $5 \mathrm{mV}$ increments. $B$, Effect of bath-applied $5 \mu \mathrm{M}$ apamin on $\mathrm{K}^{+}$currents. Shown here is the $\mathrm{K}^{+}$current recorded at $0 \mathrm{mV}$ in $2 \mu \mathrm{M}$ TTX (top trace) and in $2 \mu \mathrm{M}$ TTX plus $5 \mu \mathrm{M}$ apamin (middle trace). The bottom trace shows the apamin-sensitive current, obtained by subtracting the middle trace from the top trace. $C$, Instantaneous $(i)$ and steady-state $(i i)$ components of the apamin-sensitive current. Instantaneous measurements were made 50 msec after the beginning of the voltage step, and steady-state measurements were made $50 \mathrm{msec}$ before the end of the voltage step. Open squares, Control $\mathrm{K}^{+}$current; filled circles, $\mathrm{K}^{+}$current remaining in the presence of apamin; open triangles, apamin-sensitive $\mathrm{K}^{+}$current. $D$, Adaptation index plotted as a function of the peak instantaneous apaminsensitive $\mathrm{K}^{+}$current (triangles in $\mathrm{Ci}$ ) at depolarizations at or close to those at which the firing patterns were measured. Each point is the mean \pm SEM of seven cells.

was nearly linear, with a slope of 1.62 (Fig. 3F), and suggested that increases in the baseline membrane potential caused similar increases in both firing frequency and the magnitude of the 4-AP-sensitive $\mathrm{K}^{+}$current. The firing frequency at any given time during a maintained current injection is, however, dependent on both the preceding baseline membrane potential and the rate of repolarization of the preceding action potential. In sustainedregular cells in the $\mathrm{IC}$, action potentials reach a steady peak of approximately $+30 \mathrm{mV}$ (Fig. $2 A$ ), and the 4-AP-sensitive $\mathrm{K}^{+}$ current at $+30 \mathrm{mV}$ is $1.5 \mathrm{nA}$ in amplitude compared with the 4-AP-sensitive $\mathrm{K}^{+}$current at a baseline potential of $-25 \mathrm{mV}$, for example, which has an amplitude of $60 \mathrm{pA}$. The rate of repolarization during an action potential in these cells is also sensitive to 4-AP (Fig. 2D); therefore, it is likely that, in these cells, the magnitude of the 4-AP-sensitive $\mathrm{K}^{+}$current sets the firing frequency of the cell by both determining the baseline value of the membrane potential for any given level of current injected and contributing to the repolarization of the membrane during a single action potential.

Thus, the absence of $\mathrm{Ca}^{2+}$-activated $\mathrm{K}^{+}$conductances, and the linear dependence of the firing frequency on the magnitude of the 4-AP-sensitive $\mathrm{K}^{+}$current, suggests that the sustained-regular firing pattern is attributable predominantly to 4-AP-sensitive delayed rectifying $\mathrm{K}^{+}$channels. The slow afterhyperpolarization, however, is not attributable to either 4-AP-sensitive delayed rectifiers or $\mathrm{Ca}^{2+}$-activated $\mathrm{K}^{+}$currents sensitive to apamin or charybdotoxin. Thus, additional, as yet unidentified, $\mathrm{K}^{+}$channels are present in these cells.

\section{Sustained firing with adaptation}

In contrast to nonadapting, regularly firing cells, 29 of 73 sustained cells showed adaptation in their firing pattern during maintained depolarizing current injection. The adaptation manifested itself as a nonuniform interspike interval, in which spikes were initially close together and then gradually got further apart (Fig. 4A). The degree of adaptation and the time for which it lasted depended on the membrane potential of the cell. At lower membrane potentials, the interspike interval changed over the whole duration of the stimulus, whereas at more depolarized membrane potentials, the interspike interval changed only during the initial 200-300 msec, after which it remained constant (Fig. $4 A, B)$. For example, for the cell shown in Figure $4 B$, at a low membrane potential $(-38 \mathrm{mV})$ the interspike interval changed over the entire length of the stimulus $(1 \mathrm{sec})$, whereas at a higher membrane potential $(-28 \mathrm{mV})$, the change in interspike interval was greatest during the first $200 \mathrm{msec}$ of the response, and firing became almost regular for the remainder of the current step. The rate of change of the interspike interval, termed the "adaptation index," was determined by measuring the slope during the first 200 msec of the stimulus, at which the greatest change occurred. This adaptation index varied inversely with the magnitude of membrane depolarization and, hence, with the firing frequency (Fig. $4 C$ ). Thus, the higher the firing frequency, the smaller the adaptation.

\section{Apamin-sensitive currents account for sustained firing in adapting cells}

Neurons that exhibit adaptation as well as marked changes in firing frequency with current intensity are likely to contain transient $\mathrm{K}^{+}$currents, in addition to delayed rectifiers (Guttman and Barnhill, 1970). In the IC, adaptation, as well as increases in firing frequency, are characteristic of the firing pattern of many sustained cells and suggest the presence of additional, transient $\mathrm{K}^{+}$ currents that activate and inactivate within the time period during which adaptation occurs. Therefore, we examined cells with a sustained, adapting firing pattern for the presence of calciumdependent and other transient $\mathrm{K}^{+}$currents.

To test for the presence of $\mathrm{Ca}^{2+}$-dependent $\mathrm{K}^{+}$currents $\left(I_{\mathrm{K}(\mathrm{Ca})}\right)$, we examined the effects of $5 \mu \mathrm{M}$ apamin, which blocks the small-conductance, voltage-independent $I_{\mathrm{K}(\mathrm{Ca})}$ (Hughues et al., 1982) and charybdotoxin (100 nM), which blocks the voltage- 


\begin{tabular}{|c|c|c|c|c|c|}
\hline Firing pattern & $\begin{array}{l}\text { Resting } \\
\text { potential } \\
(\mathrm{mV})\end{array}$ & $\begin{array}{l}\text { Input } \\
\text { resistance } \\
(\mathrm{M} \Omega)\end{array}$ & $\begin{array}{l}\text { Single spike } \\
\text { AHP or } \\
\text { DAP }\end{array}$ & $\begin{array}{l}\text { Firing pattern, } \\
\text { depolarizing } \\
\text { current }\end{array}$ & $\begin{array}{l}\text { Firing pattern, } \\
\text { hyperpolarizing } \\
\text { current }\end{array}$ \\
\hline Sustained-regular & $\begin{array}{l}51.44 \pm 3.24 \\
n=14\end{array}$ & $\begin{array}{l}393.45 \pm 60.1 \\
n=10\end{array}$ & $\begin{array}{l}\text { AHP } \\
n=9\end{array}$ & $\begin{array}{l}\text { Sustained, no adaptation } \\
n=20 / 104(19.2 \%)\end{array}$ & $\begin{array}{l}\text { Anode spike, no } \\
\text { Ca-rebound }\end{array}$ \\
\hline Onset & $\begin{array}{l}59.5 \pm 6.28 \\
n=8\end{array}$ & $\begin{array}{l}643.71 \pm 86.2 \\
n=8\end{array}$ & $\begin{array}{l}\text { DAP } \\
n=4\end{array}$ & $\begin{array}{l}\text { Onset } \\
n=9 \text { of } 104(8.6 \%)\end{array}$ & $\begin{array}{l}\text { Anode spike, no } \\
\text { Ca-rebound }\end{array}$ \\
\hline Pause-build & $\begin{array}{l}51.75 \pm 3.22 \\
n=16\end{array}$ & $\begin{array}{l}355.35 \pm 69.325 \\
n=16\end{array}$ & $\begin{array}{l}\text { DAP } \\
n=12\end{array}$ & $\begin{array}{l}\text { Sustained-no adaptation } \\
n=13 \text { of } 104(12.5 \%) \\
\text { Sustained-slight adaptation } \\
n=3 \text { of } 104(2.8 \%) \\
\text { (Total } n=15.4 \%)\end{array}$ & $\begin{array}{l}\text { No anode spike, no } \\
\text { Ca-rebound }\end{array}$ \\
\hline Rebound-regular & $\begin{array}{l}51.25 \pm 3.52 \\
n=10\end{array}$ & $\begin{array}{l}352 \pm 65.128 \\
n=10\end{array}$ & $\begin{array}{l}\text { DAP } \\
n=8\end{array}$ & $\begin{array}{l}\text { Sustained, no adaptation } \\
n=11 \text { of } 104(10.6 \%)\end{array}$ & $\begin{array}{l}\text { Anode spike, } \\
\text { Ca-rebound }\end{array}$ \\
\hline Rebound-adapting & $\begin{array}{l}49 \pm 3.66 \\
n=15\end{array}$ & $\begin{array}{l}246.57 \pm 29.34 \\
n=10\end{array}$ & $\begin{array}{l}\text { AHP } \\
n=14\end{array}$ & $\begin{array}{l}\text { Sustained-adaptation } \\
n=26 \text { of } 104(25 \%)\end{array}$ & $\begin{array}{l}\text { Anode spike, } \\
\text { Ca-rebound }\end{array}$ \\
\hline Rebound-transient & $\begin{array}{l}48.11 \pm 2.08 \\
n=15\end{array}$ & $\begin{array}{l}239.49 \pm 27.86 \\
n=10\end{array}$ & $\begin{array}{l}\text { DAP } \\
n=7\end{array}$ & $\begin{array}{l}\text { Transient } \\
n=22 \text { of } 104(21.1 \%)\end{array}$ & $\begin{array}{l}\text { Anode spike, } \\
\text { Ca-rebound }\end{array}$ \\
\hline
\end{tabular}

AHP, Afterhyperpolarization; DAP, depolarizing afterpotential.

dependent maxi-K type of $I_{\mathrm{K}(\mathrm{Ca})}$ (Miller et al., 1985) on the firing pattern of sustained-adapting cells. In the presence of apamin, sustained firing was abolished $(n=7)$, and the firing pattern consisted of one or two initial spikes during the first $50 \mathrm{msec}$, followed first by a cessation of spiking, which lasted for $\sim 250-300$ msec, and then by partial recovery (Fig. 4D), during which the interval between spikes was longer than in the control. The 250-350 msec during which activity was blocked corresponded to the time during which adaptation in the discharge pattern of these cells was most pronounced (Fig. $4 A, B$ ). The longer interspike interval during recovery from apamin block indicated that the recovery was incomplete, and in addition, that the apaminsensitive $I_{\mathrm{K}(\mathrm{Ca})}$ contributed to the interspike interval during sustained firing in cells that exhibited adaptation. This effect of apamin on firing patterns in the IC is similar to that reported in other CNS neurons (Lang et al., 1997; Wang et al., 1999). Charybdotoxin had no effect on either the firing pattern during a maintained current step or the shape and duration of single action potentials (data not shown). In sustained-adapting cells, neither apamin nor charybdotoxin affected the afterhyperpolarization that follows a single action potential or that follows sustained firing (Fig. 4D,E; data shown for apamin only). This may imply the presence of apamin and charybdotoxin-insensitive calciumdependent $\mathrm{K}^{+}$currents (Sah and Isaacson, 1995) or other $\mathrm{K}^{+}$ currents not identified in this study.

To examine the characteristics of the apamin-sensitive $\mathrm{Ca}$ dependent $\mathrm{K}^{+}$currents that underlie sustained firing with adaptation, cells were voltage-clamped in the presence of TTX. The outward current exhibited a slowly inactivating component that decayed with a time constant of $300 \mathrm{msec}$ (Fig. 5Ai). When the bathing solution was changed from a normal $\mathrm{Ca}^{2+}$ concentration of $2.4 \mathrm{~mm}$ to one containing low $\mathrm{Ca}(0.1 \mathrm{~mm})$, the outward current was reduced in amplitude $(n=12)$ (Fig. 5Aii). Subtraction of the outward current in low $\mathrm{Ca}^{2+}$ from that in normal $\mathrm{Ca}^{2+}$ isolated a small $\mathrm{Ca}^{2+}$-dependent component of the outward current (Fig. 5Aiii). Like the total $\mathrm{K}^{+}$current, the calcium-dependent outward current also inactivated slowly during the $300 \mathrm{msec}$ voltage step. The total outward current (measured in normal external $\mathrm{Ca}$ ) was partially blocked by apamin $(n=6)$ (Fig. $5 B)$, whereas CTX did not affect it $(n=9)$ (Table 1 ; data not shown). Both the instantaneous and steady-state components of the $\mathrm{K}^{+}$current were reduced by apamin. The apamin-sensitive current had an activation threshold similar to that of the total $\mathrm{K}^{+}$current and accounted for $\sim 30 \%$ of it (Fig. $5 C$ ). The adaptation index obtained from current-clamp records varied with the peak apamin current measured at similar membrane potentials, with the greatest adaptation occurring at membrane potentials that evoked the smallest apamin currents (Fig. 5D). Thus, an increase in the magnitude of the apamin-sensitive $\mathrm{K}^{+}$current accompanied an increase in the number of spikes during the current injection and an increase in regular firing (Fig. 4A).

Thus, sustained firing cells that also adapt during a maintained stimulus, have, in addition to delayed rectifying $\mathrm{K}^{+}$currents, apamin-sensitive $\mathrm{K}^{+}$currents that are likely to be carried through $\mathrm{Ca}^{2+}$-dependent $\mathrm{K}^{+}$channels. These apamin-sensitive $\mathrm{K}^{+}$currents contribute to the maintenance of sustained firing during current injection in these cells. This is in contrast to sustainedregular cells, in which the firing pattern is unaffected by changes in external $\mathrm{Ca}^{2+}$, and the frequency of sustained firing is mainly governed by a 4-AP-sensitive delayed rectifier.

\section{Responses to depolarizing current: transient and onset firing in IC neurons}

\section{Multiple spike transient firing}

Some cells in the IC ( 22 of 104 cells) fired transiently during a long current step. A few action potentials were generally observed during the first 150-200 msec of the stimulus, after which the cell stopped firing altogether (Fig. 6A). Transient firing occurred at all depolarizing current levels, and in normal saline, transient firing did not change to a sustained pattern, even when the resting potential was made more negative by the injection of hyperpolarizing current. The action potentials in transiently firing cells exhibited a successive decrement in their peak amplitudes during the stimulus, and the first action potential was generally narrower than the succeeding ones. For the cell shown in Figure $6 A$, the width of the first spike (measured at half the peak height) was 0.9 


\begin{tabular}{|c|c|c|c|c|c|}
\hline $\begin{array}{l}\text { Effect of prehyper- } \\
\text { polarization on } \\
\text { first-spike latency }\end{array}$ & $2 \mathrm{~mm} 4-\mathrm{AP}\left(I_{\mathrm{K}}\right)$ & $\operatorname{Apamin}\left(I_{\mathrm{K}(\mathrm{Ca})}\right)$ & $100 \mathrm{nм} \mathrm{CTX}\left(I_{\mathrm{K}}\right)$ & $\begin{array}{l}\text { High-threshold, } \\
0.2 \mathrm{~mm} \text { TEA }\left(I_{\mathrm{K}}\right)\end{array}$ & $I_{\mathrm{K}(\mathrm{A})}$ \\
\hline $\begin{array}{l}\text { No effect } \\
n=17 \text { of } 17\end{array}$ & $\begin{array}{l}86 \pm 7.62 \% \\
n=7\end{array}$ & $\begin{array}{c}\text { Not present } \\
n=4\end{array}$ & $\begin{array}{c}\text { Not present } \\
n=4\end{array}$ & $\begin{array}{c}\text { Not present } \\
n=3\end{array}$ & $\begin{array}{c}\text { Not present } \\
n=6\end{array}$ \\
\hline $\begin{array}{l}\text { No effect } \\
n=8 \text { of } 8\end{array}$ & $\begin{array}{l}93 \pm 5.2 \% \\
n=6\end{array}$ & $\begin{array}{l}\text { Not tested. No Ca-dependent } \\
\text { firing or Ca-dependent } \mathrm{K} \\
\text { currents }\end{array}$ & $\begin{array}{l}\text { Not tested. No Ca-dependent } \\
\text { firing or Ca-dependent } \mathrm{K} \\
\text { currents. }\end{array}$ & $\begin{array}{l}45 \% \text { of total } \mathrm{K} \\
\text { current } \\
n=5\end{array}$ & $\begin{array}{l}\text { Not present } \\
n=3\end{array}$ \\
\hline $\begin{array}{l}\text { Delayed onset } \\
n=16 \text { of } 16\end{array}$ & $\begin{array}{l}73 \pm 8.75 \% \\
n=7\end{array}$ & $\begin{array}{l}\text { Small percentage }(9 \%) \text { of total } \\
\text { K current } \\
n=3 \text { of } 16 \text { cells }\end{array}$ & $\begin{array}{c}\text { Not present } \\
n=3\end{array}$ & $\begin{array}{c}\text { Not present } \\
n=4\end{array}$ & $\begin{array}{l}56.5 \% \text { of total } \mathrm{K} \\
\quad \text { current } \\
n=16\end{array}$ \\
\hline $\begin{array}{l}\text { No effect } \\
n=10 \text { of } 10\end{array}$ & $\begin{array}{l}79 \pm 12.34 \% \\
n=5\end{array}$ & $\begin{array}{l}\text { Not present } \\
n=4\end{array}$ & $\begin{array}{c}\text { Not present } \\
n=4\end{array}$ & $\begin{array}{l}\text { Not present } \\
n=2\end{array}$ & $\begin{array}{l}\text { Not present } \\
\quad n=3\end{array}$ \\
\hline $\begin{array}{l}\text { No effect } \\
n=26 \text { of } 26\end{array}$ & $\begin{array}{l}41 \pm 7.3 \% \\
n=6\end{array}$ & $\begin{array}{l}30 \% \text { of total K current } \\
\quad n=11\end{array}$ & $\begin{array}{c}\text { Not present } \\
n=9\end{array}$ & $\begin{array}{c}\text { Not present } \\
n=4\end{array}$ & $\begin{array}{c}\text { Not present } \\
n=6\end{array}$ \\
\hline $\begin{array}{l}\text { No effect } \\
n=20 \text { of } 20\end{array}$ & $\begin{array}{l}52 \pm 9.8 \% \\
n=3\end{array}$ & $\begin{array}{l}\text { Not present } \\
n=5\end{array}$ & $\begin{array}{l}55 \% \text { of total K current } \\
\quad n=8\end{array}$ & $\begin{array}{c}\text { Not present } \\
n=7\end{array}$ & $\begin{array}{c}\text { Not present } \\
n=3\end{array}$ \\
\hline
\end{tabular}

msec, whereas the action potentials that followed it had widths of 2.3-3.4 msec at half the peak height.

The transient nature of the firing pattern was unaffected by 2 mM 4-AP (data not shown) but was greatly altered by charybdotoxin. The addition of $100 \mathrm{~nm} \mathrm{CTX} \mathrm{to} \mathrm{the} \mathrm{external} \mathrm{saline} \mathrm{changed}$ transient firing to sustained firing but left the interspike interval unchanged $(n=7)$ (Fig. 6Bi,Bii). In addition, CTX abolished the afterhyperpolarization that follows a single action potential $(n=$ 7) (Fig. 6Biii). Activation of a CTX-sensitive $I_{\mathrm{K}}$ was thus directly responsible for transient activity in cells capable of sustained firing. In normal saline, spike heights of successive action potentials decreased and spike widths increased with time during the current pulse (Fig. 6Ci,Cii, top graphs). However, charybdotoxin altered these trends to some extent; spike heights did not decrease as much and spike widths did not increase as much when the CTX-sensitive current was blocked (Fig. 6Ci,Cii, bottom graphs).

$\mathrm{K}^{+}$currents underlying firing in multiple spiking transient cells In transiently firing cells, outward currents had two components: a rapidly inactivating transient component and a second non-inactivating current (Fig. 7Ai). The decay time constant of the rapid component changed with the magnitude of the voltage step. For the cell shown in Figure $7 A i$, this decay time constant was $3.6 \mathrm{msec}(4.2 \pm 1.8 ; n=15)$ at a voltage of -30 $\mathrm{mV}$, increased to $5.6 \mathrm{msec}(9.8 \pm 4.4 ; n=15)$ at $0 \mathrm{mV}$, after which it decreased to $2.6 \mathrm{msec}(2.6 \pm 1.1 ; \mathrm{n}=15)$ at $+20 \mathrm{mV}$. Because the total whole-cell current was being recorded, the values of the time constant are likely to reflect both the inactivation time constant of the outward $\mathrm{K}^{+}$current and the activation of an inward $\mathrm{Ca}^{2+}$ current, which is likely to reach its peak amplitude at approximately $+20 \mathrm{mV}$. Thus, the time constant of the transient $\mathrm{K}^{+}$current alone is likely to be longer than that of the total current measured in Figure $7 \mathrm{Ai}$.

The transient component was abolished in low $\mathrm{Ca}^{2+}(n=8)$ (Fig. 7Aii). The current resulting from subtracting the current in low $\mathrm{Ca}^{2+}$ from the total outward current in normal $\mathrm{Ca}^{2+}$ consisted of a rapidly inactivating outward current (presumably a $\mathrm{Ca}^{2+}$-activated $\mathrm{K}^{+}$current), followed by an inward current (presumably a $\mathrm{Ca}^{2+}$ current) $\left(I_{\mathrm{K}(\mathrm{Ca})}\right.$ and $\left.I_{\mathrm{Ca}}\right)$ (Fig. 7 Aiii). The total outward current measured in TTX and normal external $\mathrm{Ca}^{2+}$ (shown in Fig. 7Ai) was unaffected by apamin $(n=5$; data not shown). In 100 nм CTX, the rapid component disappeared completely, and the non-inactivating component was partially blocked $(n=8)$ (Fig. 7Bi). The CTX-sensitive current had a rapid, transiently decaying component, with a time constant of inactivation of $50 \pm 7 \mathrm{msec}(n=8)$, which presumably flowed through maxi-K $\mathrm{Ca}^{2+}$-dependent $\mathrm{K}^{+}$channels, and a non-inactivating current, which may have been attributable to other delayedrectifying $\mathrm{K}^{+}$channels that were blocked by CTX (Fig. 7Bii). The peak transient CTX-sensitive $I_{\mathrm{K}}$ accounted for $\sim 55 \%$ of the total outward current (Fig. 7Biii). When the CTX concentration was increased to $1 \mu \mathrm{M}, 80 \%$ of the $\mathrm{K}^{+}$current was blocked (data not shown), suggesting that $\mathrm{Ca}^{2+}$-independent CTX-sensitive $\mathrm{K}^{+}$channels are present in these cells.

\section{Single spike onset firing}

Nine of 104 cells in the IC fired only once at the beginning of a $300 \mathrm{msec}$ depolarizing current step, and additional spiking activity was not observed with increasing current strengths (Fig. 8A). This firing pattern corresponded to the onset firing pattern described by Peruzzi et al. (2000) and was not attributable to damage-induced lack of sustained firing, because hyperpolarization of these cells with current did not produced any additional firing. These cells also had higher input resistances and membrane time constants than other neurons in our sample (Table 1), supporting the view that the lack of multiple spikes was not the result of damage to the cell. These cells were thus regarded as onset cells, and their classification as a distinct cell type was supported by the presence of $\mathrm{K}^{+}$currents unique to them.

The onset pattern to current injection in the IC is similar to that seen in lower auditory brainstem nuclei, such as the medial nucleus of the trapezoid body (MNTB) (Brew and Forsythe, 1995) and bushy cells in the anterior ventral cochlear nucleus (AVCN) (Manis and Marx, 1991) of the rat and in the chick nucleus magnocellularis (Reyes et al., 1994; Zhang and Trussell, 1994; Sivaramakrishnan and Laurent, 1995). In the MNTB and the AVCN, onset firing is associated with low-threshold (approximately $-60 \mathrm{mV}$ ) and high-threshold (approximately -30 to -20 


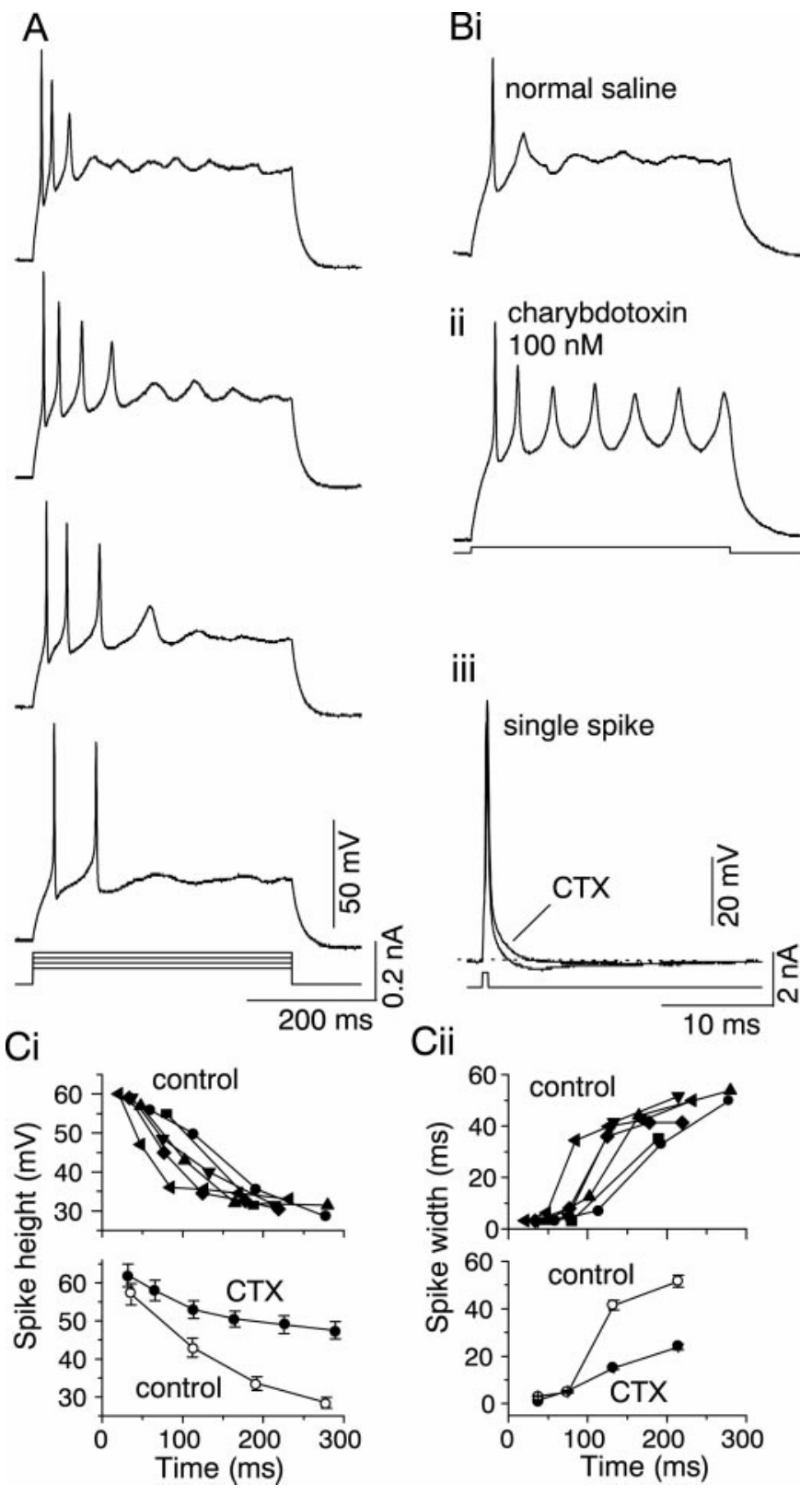

Figure 6. Transient firing in an IC neuron and effect of charybdotoxin. $A$, Transient firing in normal saline during 300-msec-long current pulses injected into the soma. Depolarization increases from bottom to top. $B$, Firing pattern recorded in normal saline $(i)$ and $100 \mathrm{~nm}$ charybdotoxin (ii) in a transiently firing neuron. Current pulse magnitude is $0.2 \mathrm{nA}$. iii, Action potentials recorded in the presence and absence of CTX. Each action potential shown is the average of five trials. $\mathrm{Ci}$, Plot of spike height in the presence and absence of CTX. Top shows changes in spike height plotted as a function of the time from the start of the current injection for a single cell. The curves represent spike heights versus time at different membrane potentials. Bottom shows the effect of CTX on spike height at a membrane potential of $-30 \mathrm{mV}$. Mean \pm SEM of four cells. ii, Plot of spike width versus time at different membrane potentials (top) for one cell and in the presence and absence of CTX at a membrane potential of -30 $\mathrm{mV}$. Mean \pm SEM of four cells.

$\mathrm{mV}$ ) delayed-rectifying $\mathrm{K}^{+}$currents, which are, respectively, blocked by dendrotoxin-I and low concentrations $(0.2 \mathrm{~mm})$ of TEA-Cl (Manis and Marx, 1991; Forsythe and Barnes-Davies, 1993; Brew and Forsythe, 1995; Wang et al., 1998). We therefore examined the possible existence of these currents in onset cells in the IC and their underlying role in onset firing.
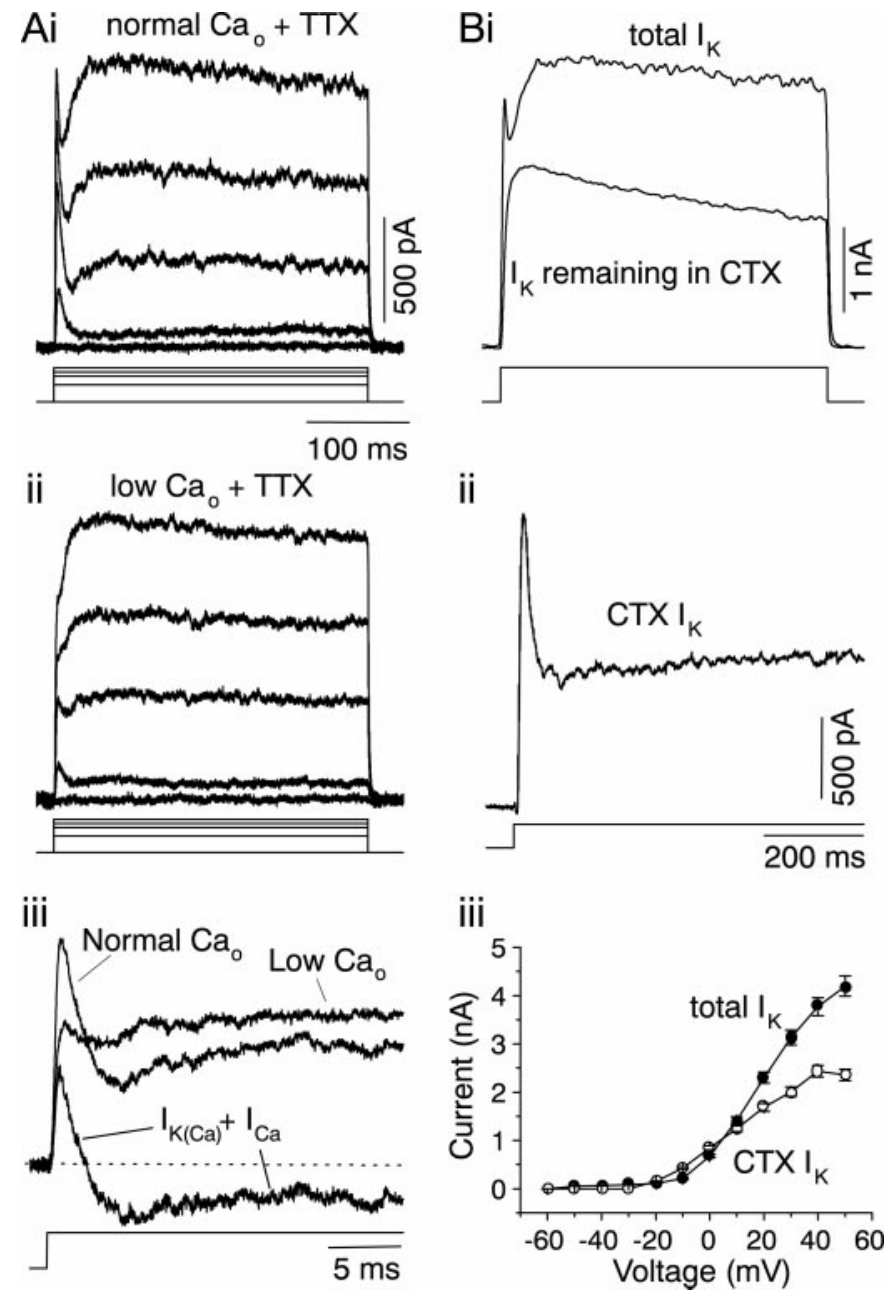

Figure 7. $\mathrm{Ca}^{2+}$-dependent $\mathrm{K}^{+}$currents in a transiently firing cell. $A, \mathrm{~K}^{+}$ currents recorded in saline containing $2 \mu \mathrm{M}$ TTX and normal $\mathrm{Ca}^{2+}(i ; 2.4$ $\mathrm{mm}$ ) and low $\mathrm{Ca}^{2+}(i i ; 0.1 \mathrm{~mm})$. The cell was held at $-60 \mathrm{mV}$ and stepped to different voltages. Voltage steps shown here are $-60,-10,+10,+20$, and $+30 \mathrm{mV}$. iii, Superimposed, expanded traces of the outward current evoked at $+30 \mathrm{mV}$ in normal $\mathrm{Ca}^{2+}$, low $\mathrm{Ca}^{2+}$, and the current resulting from the subtraction of the two. The subtracted current is composed of an outward $\mathrm{K}^{+}$current $\left(I_{\mathrm{K}(\mathrm{Ca})}\right)$ and an inward $\mathrm{Ca}^{2+}$ current $\left(I_{\mathrm{Ca}}\right)$. B, Effect of charybdotoxin on the outward current in transient cells. $i$, The total $\mathrm{K}^{+}$ current and the current remaining after bath application of $100 \mathrm{nM}$ CTX during a voltage step to $+30 \mathrm{mV}$ from a holding potential of $-60 \mathrm{mV}$. $i$, The CTX-sensitive current obtained by subtracting the current remaining in CTX from the total $\mathrm{K}^{+}$current. The time constant of inactivation of the fast component was $50 \mathrm{msec}$ in this cell. iii, Steady-state currentvoltage relationship of the total $I_{\mathrm{K}}$ and the CTX-sensitive $I_{\mathrm{K}}$. Mean \pm SEM of five cells.

Action potentials were recorded under current clamp in the presence of TEA and 4-AP. Blocking the high-threshold current with $0.2 \mathrm{~mm}$ TEA-Cl broadened the duration of the single onset spike evoked during a $300 \mathrm{msec}$ current step $(n=3)$. In the example shown in Figure $8 B$, the addition of $0.2 \mathrm{~mm}$ TEA-Cl changed the spike duration from $1.5 \mathrm{msec}$ measured at halfamplitude to $4.3 \mathrm{msec}$ (inset) but did not produce any additional spiking activity. The addition of $0.2 \mathrm{~mm} 4$-AP had similar effects on onset firing $(n=3)$. The broadening of the onset spike, but the lack of additional spiking activity, suggested that the highthreshold delayed rectifier contributed to the repolarization of the membrane over the time course of a single action potential but did not contribute to the onset behavior of the cell. To 


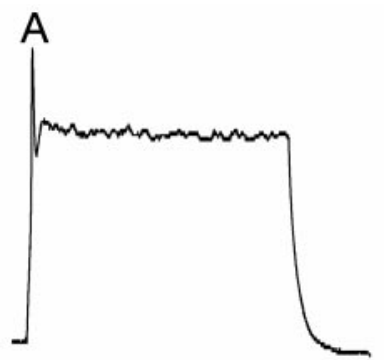

B
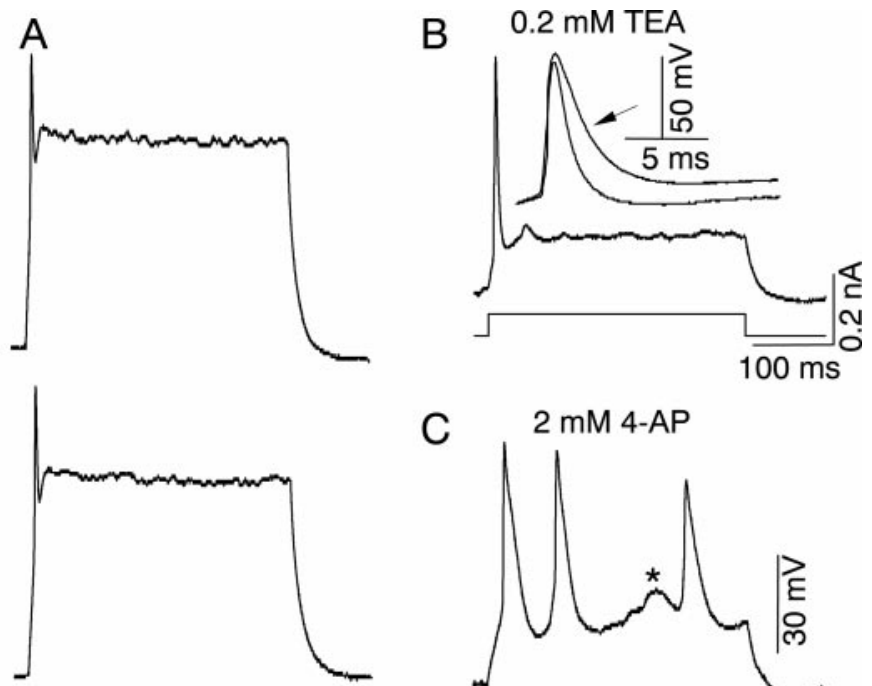

C
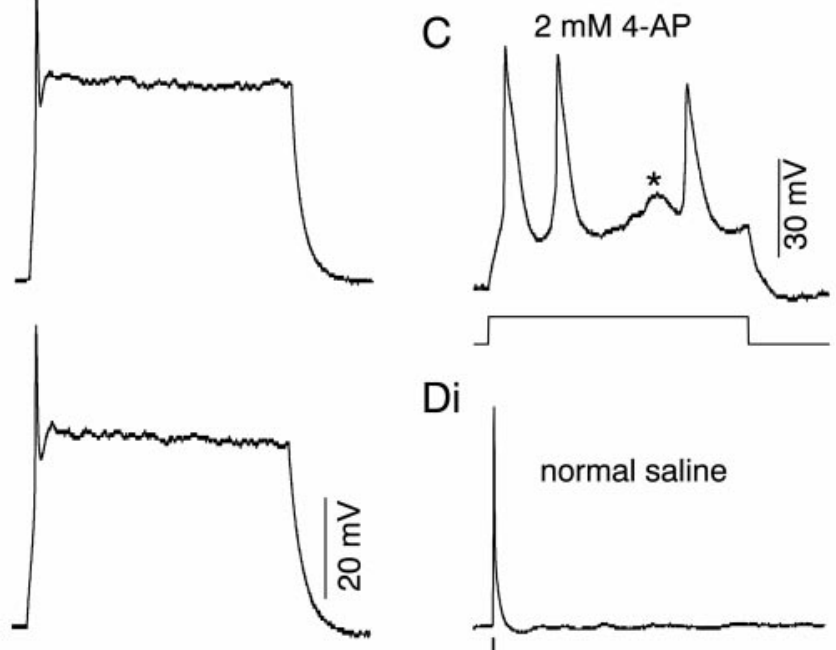

Di
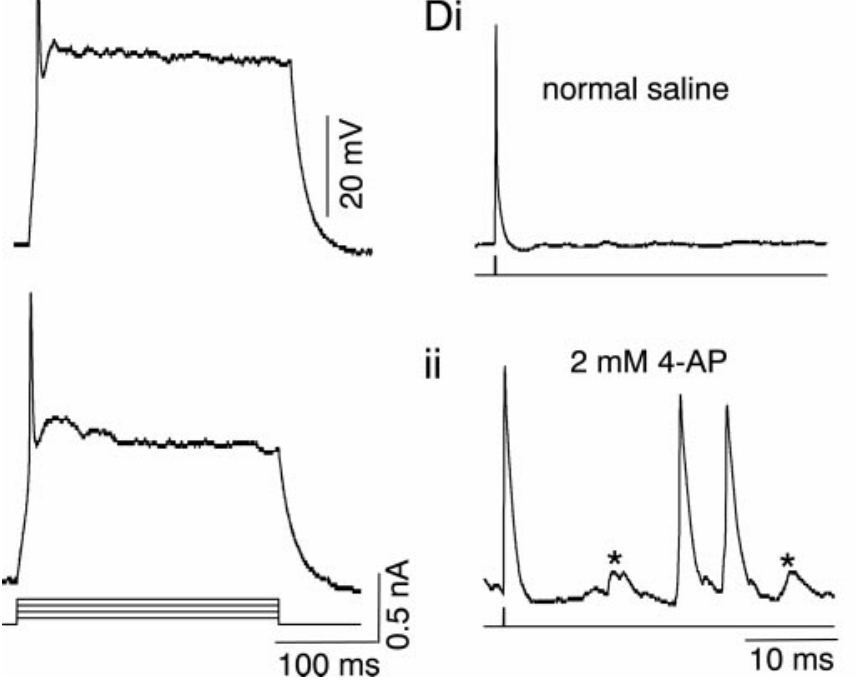

Figure 8. The onset firing pattern and effect of $\mathrm{K}^{+}$channel blockers. $A$, Current-clamp records of firing pattern in normal saline. Depolarizing current pulses are 300-msec-long. Depolarization increases from bottom to top. B, Firing pattern in the presence of $0.2 \mathrm{mM}$ TEA-Cl during a 300-msec-long current step injected into the soma. Inset, The onset spike in control and TEA-Cl-containing solutions has been expanded to show the duration of the single spike. The duration of the onset spike is 1.5 msec at half-width in normal saline and $4.3 \mathrm{msec}$ in the presence of TEA-Cl. $C$, Firing pattern of an onset cell in 2 mM 4-AP during a 300 -msec-long current pulse. $D$, Spike activity in an onset cell in normal saline $(i)$ and $2 \mathrm{~mm} 4-\mathrm{AP}(i i)$ evoked by a single short duration $(0.2 \mathrm{msec})$ current pulse. Asterisks in $C$ and Dii indicate either aborted action potentials or excitatory synaptic potentials.

examine the contribution of the low-threshold current to the onset firing pattern, we used high concentrations of 4-AP (2 mM), which blocks both high- and low-threshold delayed-rectifier $\mathrm{K}^{+}$ currents. In contrast to $0.2 \mathrm{~mm}$ TEA-Cl, $2 \mathrm{~mm} 4$-AP caused multiple spiking in the cell during 300 -msec-long current pulses, and it broadened the action potentials (Fig. $8 C$ ). Short current pulses ( $0.2 \mathrm{msec}$ duration) that normally evoked a single action potential in onset cells (Fig. $8 \mathrm{Di}$ ) evoked multiple firing in the presence of high concentrations of 4-AP (Fig. 8Dii). This suggested that some of the additional spikes observed in $2 \mathrm{~mm} 4$-AP were not necessarily evoked directly by the injected current pulse

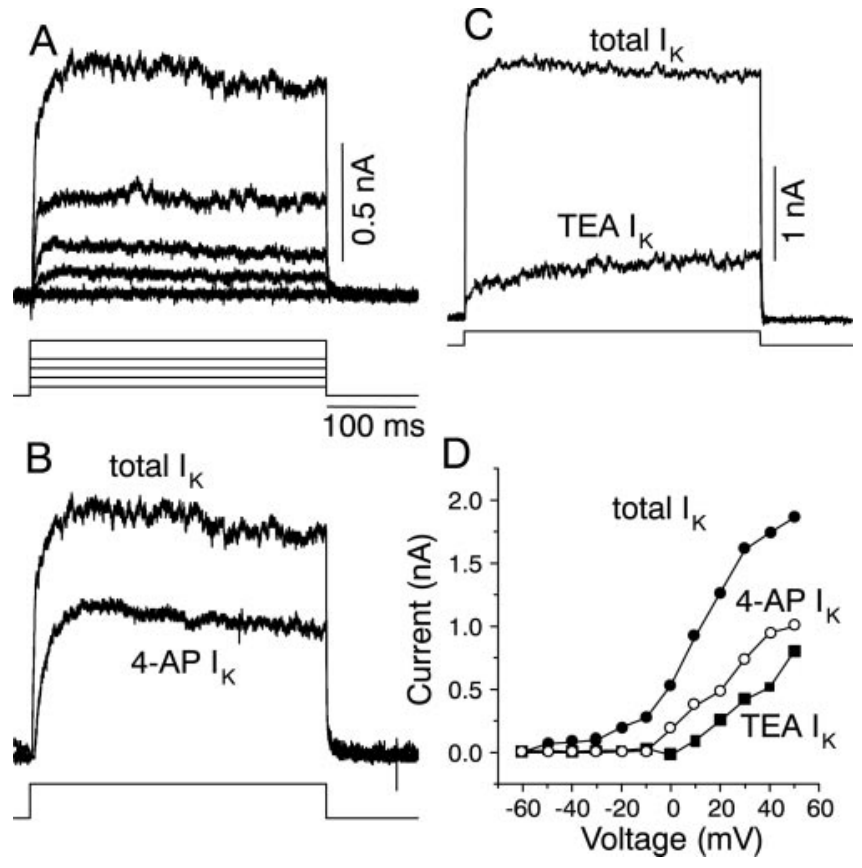

Figure 9. $\mathrm{K}^{+}$currents in onset cells. A, Voltage-clamp records of $\mathrm{K}^{+}$ currents in the presence of normal saline containing $1 \mu \mathrm{M}$ TTX. Voltage steps shown here are $-50,-40,-30,-20$, and $0 \mathrm{mV}$ from a holding potential of $-60 \mathrm{mV}$. B, Effect of $0.2 \mathrm{~mm} 4-\mathrm{AP}$ on $\mathrm{K}^{+}$currents. The 0.2 $\mathrm{mm}$ 4-AP-sensitive current was obtained by subtracting the current remaining in $0.2 \mathrm{~mm}$ 4-AP (data not shown) from the total $\mathrm{K}^{+}$current evoked in the absence of 4-AP. The currents shown here were evoked during a voltage step to $0 \mathrm{mV}$. $C$, Effect of $0.2 \mathrm{~mm}$ TEA-Cl on $\mathrm{K}^{+}$ currents. Superimposed traces of the total $\mathrm{K}^{+}$current and the TEA-Clsensitive $\mathrm{K}^{+}$current, obtained by subtracting the current remaining in TEA-Cl (data not shown) from the total $\mathrm{K}^{+}$current. $D$, Steady-state voltage-current relationships of the control $\mathrm{K}^{+}$current and the $0.2 \mathrm{~mm}$ TEA-Cl- and $0.2 \mathrm{~mm}$ 4-AP-sensitive currents. Steady-state values of current were measured $50 \mathrm{msec}$ before the end of the $300 \mathrm{msec}$ voltage step. Mean \pm SEM of four cells in TEA-Cl and three cells in 4-AP.

but could have been generated by excitatory synapses made onto the onset cell (Fig. 8C,Dii, asterisks). Thus, the low-threshold delayed rectifier restricts the firing of the cell to the onset of the stimulus pulse. Onset cells did not change their firing pattern in saline containing low $\mathrm{Ca}^{2+}(n=4)$.

\section{$\mathrm{K}^{+}$currents underlying onset firing}

Outward currents in onset cells activated between -50 and -40 $\mathrm{mV}(n=9)$ and showed little inactivation during a $300 \mathrm{msec}$ voltage step (Fig. $9 A$ ). Addition of $0.2 \mathrm{~mm} \mathrm{4-AP}$ to the bathing solution of the cell partially blocked the outward current $(n=4)$ (Fig. 9B), as did the addition of $0.2 \mathrm{~mm}$ TEA-Cl $(n=5)$ (Fig. 9C). The steady-state 4-AP- and TEA-Cl-sensitive components (obtained by subtracting the current remaining in 4-AP or TEA-Cl from the total outward current) each represented $\sim 45 \%$ of the total outward current and activated at higher voltages than the total $\mathrm{K}^{+}$current $(-10$ to $0 \mathrm{mV}$ for the 4-AP-sensitive component and 0 to $+10 \mathrm{mV}$ for the TEA-sensitive component) (Fig. 9D). These data suggested that high-threshold $\mathrm{K}^{+}$currents, similar to those observed in the cochlear nucleus and MNTB, were present in onset cells in the IC. Neither the $\mathrm{K}^{+}$currents nor the firing pattern were affected by decreasing the external $\mathrm{Ca}^{2+}$ concentration (from the normal concentration of 2.4-0.1 mM; $n=4$ ). This result suggests the absence of $\mathrm{Ca}^{2+}$-activated $\mathrm{K}^{+}$currents in onset cells. Thus, onset cells in the IC contain low- and 

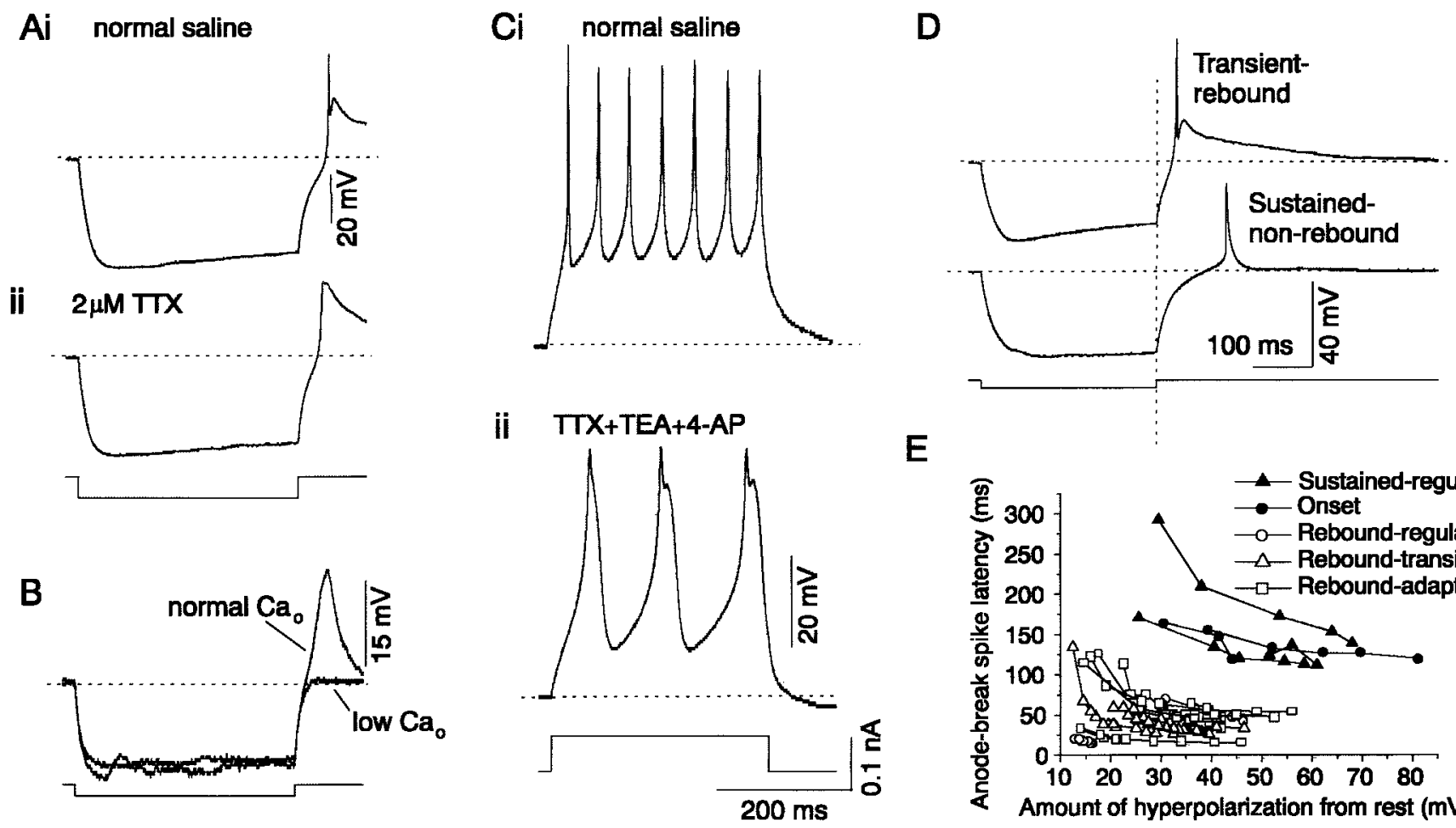

E

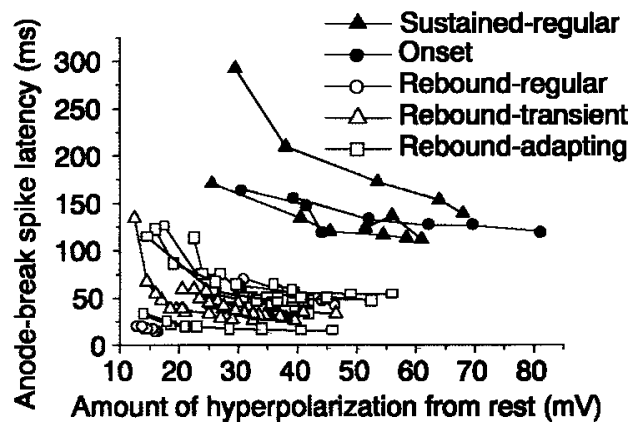

Figure 10. Calcium-dependent rebound depolarization in IC neurons. $A$, Response of an IC neuron to a hyperpolarizing current pulse in normal saline (i) and saline containing $2 \mu \mathrm{M}$ TTX $(i i) . B$, Response of the same cell to a hyperpolarizing current pulse in normal $(2.4 \mathrm{~mm})$ and low Ca ${ }^{2+}(0.1 \mathrm{~mm})$ saline containing $2 \mu \mathrm{M}$ TTX. $C$, Sustained firing in the same IC neuron during a depolarizing current pulse in normal saline $(i)$ and saline containing $2 \mu \mathrm{M}$ TTX, $10 \mathrm{~mm}$ TEA-Cl, and $2 \mathrm{~mm}$ 4-AP $(\mathrm{ii}) . D$, Response to a hyperpolarizing current pulse showing the anode-break spike latencies of a transiently firing IC neuron that exhibited a calcium-dependent rebound depolarization and a sustained firing IC neuron that did not exhibit a calcium-dependent rebound from hyperpolarization. The vertical dotted line coincides with the end of the current pulse, and the horizontal dotted lines indicate the resting potentials of each cell. $E$, Anode-break spike latencies plotted as a function of the amount of hyperpolarization for cells with different firing patterns (for explanations of the different firing patterns, see Fig. 13 and the accompanying text) indicate a bimodal distribution of latencies in the IC.

high-threshold non-inactivating $\mathrm{K}^{+}$currents, whose kinetics and pharmacological properties differ from those in multiple spiking transient cells, as well as in sustained cells.

\section{Responses to hyperpolarizing current}

Responses to depolarizing current pulses, described in the preceding paragraphs, divided firing patterns in the IC into four classes: sustained-regular, sustained-adapting, transient, and onset. The injection of hyperpolarizing current pulses into cells that exhibited these four firing patterns resulted in two additionally distinct responses to the hyperpolarization. These two responses were exhibited by either or both sustained and transient cells, but not by onset cells, and resulted in the addition of two more cell classes to the four already described.

\section{$\mathrm{Ca}^{2+}$-dependent rebound depolarizations in transient and sustained neurons}

When hyperpolarizing current steps were injected into IC neurons, anode-break spikes were typically observed upon release of the hyperpolarizing current (93 of 104 cells). In some IC neurons, however ( $n=59$ of 104), the anode-break spike was followed by a broad, rebound depolarization (Fig. 10 Ai, arrow). This rebound was observed in all transiently firing cells (22 cells) and in a subset of sustained cells that showed both regular and adapting firing patterns during the injection of depolarizing current (37 of 73 sustained cells) but not in onset cells. Of these 37 sustained cells that exhibited the rebound depolarization, 26 were sustainedadapting cells, and 11 were sustained-regular cells. Because the total number of sustained-adapting cells from which recordings were made in this study was 29 , and the total number of sustainedregular cells was $44, \sim 90 \%$ of the sustained-adapting cells (26 of 29 ) showed the rebound depolarization, whereas the rebound was present in only $25 \%$ of the sustained-regular cells (11 of 44).

In both rebound and nonrebound IC neurons, the anode-break spikes disappeared in $2 \mu \mathrm{M}$ TTX, indicating that they were sodium spikes (Fig. 10Aii; data shown for rebound cells only). The slower rebound depolarization, however, was unaffected by TTX and was blocked in a reversible manner when the external calcium concentration was reduced to $0.1 \mathrm{~mm}(n=23)$ (Fig. 10B) or when $0.5 \mathrm{~mm}$ cadmium chloride was added to the saline $(n=$ 6) (data not shown), suggesting that it was attributable to currents flowing through calcium channels. In addition to the calciumdependent rebound depolarization, rebound cells also exhibited regenerative calcium spikes during depolarizing current steps, when sodium and potassium channel blockers (TTX plus TEA plus 4 -AP) were present $(n=11)$. The spikes were typically $\sim 100$ msec in duration (Fig. 10C) and were abolished by the removal of external calcium or the addition of $0.5 \mathrm{~mm}$ cadmium chloride to the external solution ( $n=8$; data not shown). Two components were evident on most spikes: an initial taller spike followed by a second, shorter component, which were likely to have been generated at different locations in the cell.

A characteristic difference between cells that exhibited the calcium-dependent rebound and cells that did not was the latency of the sodium-dependent anode-break spike from the end of the 
hyperpolarizing current step. When the calcium-dependent rebound was present, the anode-break spike occurred with a smaller delay after the end of the hyperpolarizing pulse compared with its delay in cells that did not exhibit the calcium rebound. Figure $10 \mathrm{D}$ illustrates this difference between the latencies of the anodebreak spike in a transiently firing cell that exhibited a calciumdependent rebound depolarization and a sustained-regular cell in which such a rebound depolarization was absent. For a similar amount of hyperpolarization (e.g., $\sim 40 \mathrm{mV}$ more negative than the resting potential), the anode-break spike occurred with a latency of $30 \mathrm{msec}$ in the cell with the rebound and $128 \mathrm{msec}$ in the cell without the rebound. In cells with and without the calcium rebound, the anode-break spike was produced with smaller delays with increasing hyperpolarizations, which is expected from the more rapid removal of sodium channel inactivation with larger hyperpolarizations. In rebound cells, at very small hyperpolarizations, $\sim 5 \mathrm{mV}$ from the resting potential of the cell, a calcium-dependent depolarization was sometimes absent, and at these hyperpolarizations, the anode-break spike had a longer latency, similar to that observed in cells that did not exhibit a rebound at any level of hyperpolarization. A second characteristic difference between rebound and nonrebound cells was that anode break spikes were routinely observed at smaller hyperpolarizations in rebound cells (Fig. 10E). Sustained and onset cells that did not exhibit a rebound depolarization exhibited anode-break spikes only at hyperpolarizations larger than $\sim 25 \mathrm{mV}$ from rest (which resulted in a membrane potential of approximately -85 $\mathrm{mV}$ ), whereas cells that did exhibit a rebound depolarization had anode-break spikes, even at hyperpolarizations as small as $10 \mathrm{mV}$ (membrane potential of $-70 \mathrm{mV}$ ). Thus, it appears that the calcium entry that leads to the rebound depolarization may function, first, to increase the probability that anode-break spikes are produced at smaller hyperpolarizations, and second, to decrease the latency of the anode-break spike.

\section{The buildup-pause response in sustained neurons}

A small fraction of sustained cells (16 of 74) were characterized by a delay in the onset of their firing when the depolarizing current step used to evoke sustained firing (Fig. 11 $\mathrm{Ai}$ ) was preceded by a hyperpolarizing current step (Fig. 11Aii) (Peruzzi et al., 2000). The nature of the delay in firing onset depended on the magnitude of the depolarization that followed the hyperpolarizing step. When the depolarization was $<20 \mathrm{mV}$, the delay in the onset of firing was characterized by a hump, sag, and gradual buildup of membrane potential toward firing threshold (the buildup response) (Fig. 11 Aii, arrow), after which sustained firing was observed. If the depolarization was increased, the cell fired one spike at the onset of the depolarizing current injection step and then paused before firing again in a sustained manner (the pause response) (Fig. 11 Aiii, arrow). The duration of the buildup or pause effect varied proportionally with the magnitude of the prehyperpolarization (Fig. $11 B$ ). A prehyperpolarization to -100 $\mathrm{mV}$ caused a pause-build response that lasted for $\sim 50 \mathrm{msec}(n=$ 16) (Fig. 11C). As the prehyperpolarization decreased from -100 to $-70 \mathrm{mV}$, the pause-buildup time decreased from 50 to 15 msec. It reached $0 \mathrm{msec}$ at a prehyperpolarization of $-67 \mathrm{mV}$, which was, on average, $\sim 10 \mathrm{mV}$ more hyperpolarized than the resting potential of these cells. This pause-build firing pattern was not observed in cells with a transient or onset firing pattern or in cells that exhibited a calcium-dependent rebound response to hyperpolarization (Table 1).

A pause-build pattern of firing similar to the one seen in IC
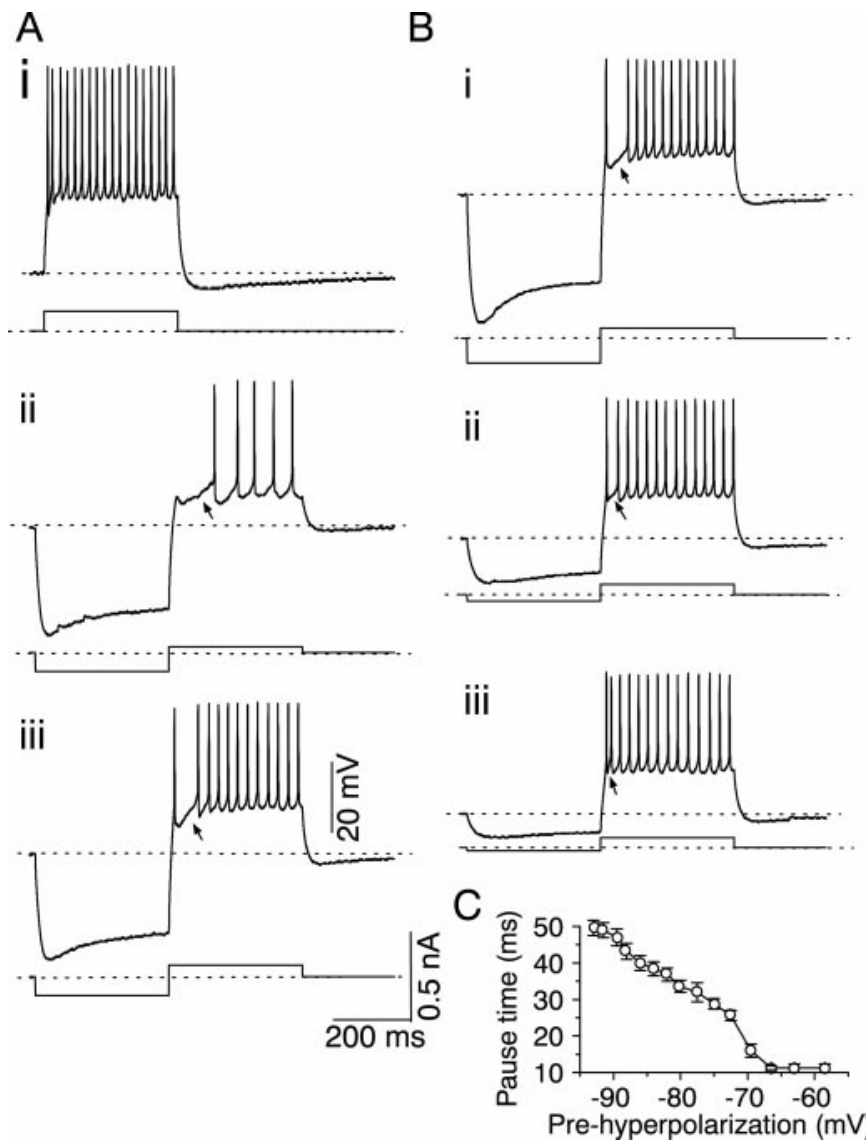

Figure 11. Build-up and pause responses in a pause-build cell after prehyperpolarization. $A$, Current-clamp recordings of firing patterns in the absence $(i)$ and the presence (ii, iii) of prehyperpolarization. The prehyperpolarization magnitudes are the same in $i i$ and $i i i$, but the depolarizing step is larger in iii than in ii. Arrows point to the buildup of membrane potential toward threshold for firing. $B$, Firing pattern of the same cell following different magnitudes of prehyperpolarization. The magnitude of the depolarizing current was chosen to produce a pause instead of a buildup and is the same for all three traces. Arrows point to the pause in firing. Recordings in $A$ and $B$ are from the same cell. $C$, Relationship between pause time and magnitude of prehyperpolarization. The pause time was measured as the time between the peaks of the first and second spikes. The prehyperpolarization is the value of the membrane potential at different current levels. Mean \pm SEM of 14 cells.

neurons has been described in other invertebrate and vertebrate neurons and is caused by the removal of inactivation of an A-type $\mathrm{K}^{+}$channel by prehyperpolarization and its subsequent activation by depolarization (Connor and Stevens, 1971a,b; Neher, 1971; Kim et al., 1994; Kanold and Manis, 1999). We therefore examined pause-build cells in the IC for the presence of an A-type potassium current $\left(I_{\mathrm{K}(\mathrm{A})}\right)$.

\section{$K^{+}$currents underlying the buildup-pause phenomenon}

$\mathrm{K}^{+}$currents were recorded under voltage clamp in the presence of TTX and low $\mathrm{Ca}^{2+}(0.1 \mathrm{~mm})$ in all of the buildup-pause cells from which recordings were made $(n=16)$. To activate $I_{\mathrm{K}(\mathrm{A})}$, the cell was held at $-60 \mathrm{mV}$ for $10 \mathrm{msec}$ and then hyperpolarized to $-100 \mathrm{mV}$ for $500 \mathrm{msec}$, followed by a depolarizing voltage step to $-10 \mathrm{mV}$ for $300 \mathrm{msec}$. This protocol resulted in the activation of an outward current with a transient, inactivating component, followed by a non-inactivating component (Fig. $12 \mathrm{Ai}$ ). To isolate $I_{\mathrm{K}(\mathrm{A})}$ from the other $\mathrm{K}^{+}$currents activated during the depolarizing voltage step, the cell was held at $-60 \mathrm{mV}$ and then prede- 


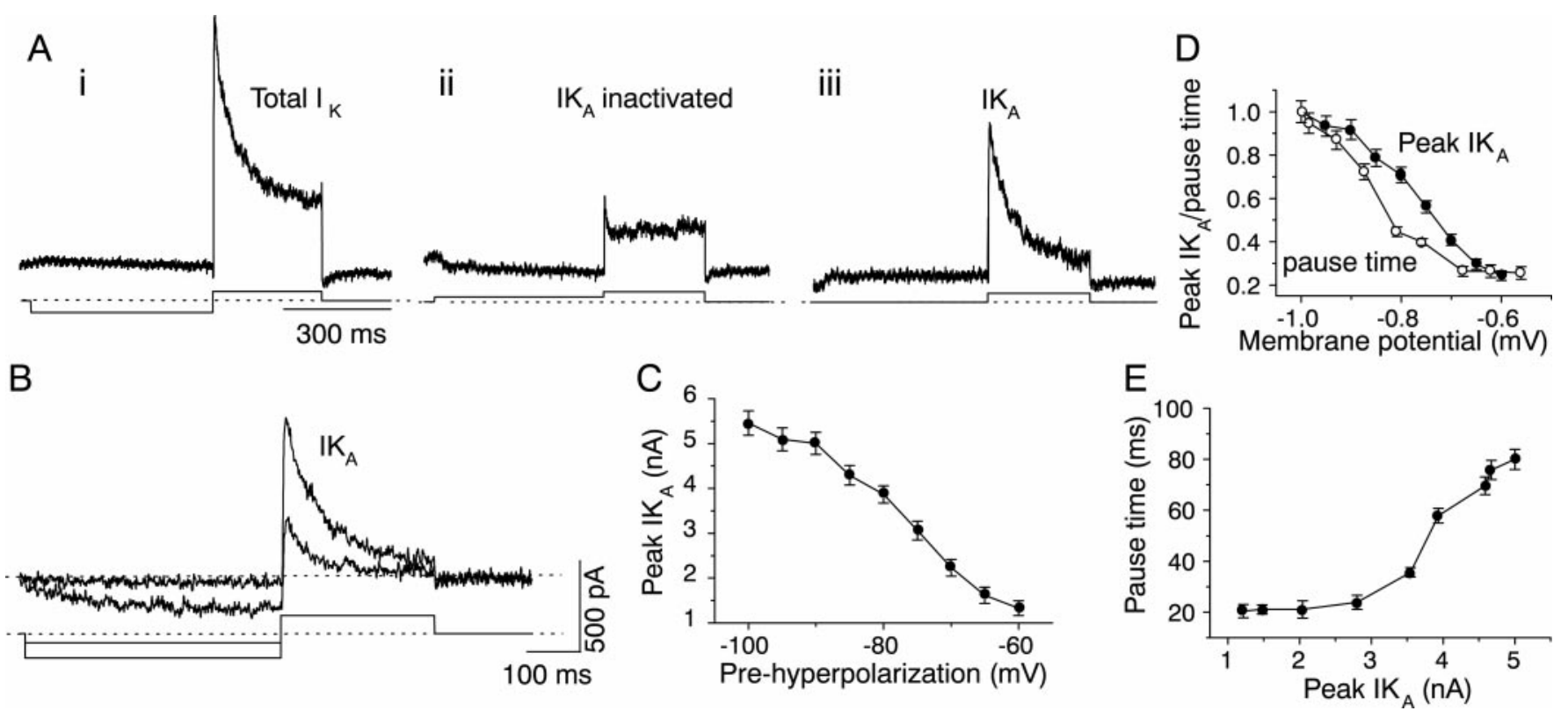

Figure 12. $I_{\mathrm{K}(\mathrm{A})}$ in pause-build neurons. $\mathrm{K}^{+}$currents were recorded in saline containing $2 \mu \mathrm{M}$ TTX. A, Isolation of $I_{\mathrm{K}(\mathrm{A})} \cdot i$, Bottom trace, The voltage-clamp protocol used to test for the presence of $I_{\mathrm{K}(\mathrm{A})}$. The cell was held at $-60 \mathrm{mV}$ and then prehyperpolarized to $-100 \mathrm{mV}$ for $500 \mathrm{msec}$, followed by a depolarization to $-10 \mathrm{mV}$ for $300 \mathrm{msec}$ to evoke $\mathrm{K}^{+}$efflux and then returned to its holding potential. Top trace, $\mathrm{K}^{+}$current evoked by this protocol. There was no measurable $\mathrm{K}^{+}$current during the prehyperpolarizing step in this cell. $i i$, Bottom trace, Protocol used to inactivate $I_{\mathrm{K}(\mathrm{A})}$. The cell was held at $-60 \mathrm{mV}$, predepolarized to $-30 \mathrm{mV}$ for $500 \mathrm{msec}$, followed by a depolarization to $-10 \mathrm{mV}$, and then returned to its resting potential. Top trace, $\mathrm{K}^{+}$current during the $300 \mathrm{msec}$ depolarization to $-10 \mathrm{mV}$. iiii, The $\mathrm{K}^{+}$current remaining after subtraction of $i i$ from $i$ shows the time course and magnitude of $I_{\mathrm{K}(\mathrm{A})}$ evoked during the voltage step to $-10 \mathrm{mV} . B, I_{\mathrm{K}(\mathrm{A})}$ evoked by prehyperpolarizations of two different magnitudes; the larger prehyperpolarization evokes the larger $I_{\mathrm{K}(\mathrm{A})}$. Current traces shown are the subtracted traces resulting from a similar protocol to the one used in $A$, except that the prehyperpolarization was varied. In this cell, a small inward current is triggered by the larger hyperpolarizing step. $C, I_{\mathrm{K}(\mathrm{A})}$ has a monotonic dependence on the magnitude of the prehyperpolarization. $D$, Similar variation of pause time and $I_{\mathrm{K}(\mathrm{A})}$ with the magnitude of prehyperpolarization. $E$, Variation of pause time with peak $I_{\mathrm{K}(\mathrm{A})}$ amplitude. Data in $C-E$ are the mean \pm SEM of the same 11 cells.

polarized to $-20 \mathrm{mV}$ for $500 \mathrm{msec}$, followed by a depolarizing step to $-10 \mathrm{mV}$ for $300 \mathrm{msec}$. The predepolarizing step to $-20 \mathrm{mV}$ inactivated $I_{\mathrm{K}(\mathrm{A})}$, which was therefore not activated during the voltage step to $-10 \mathrm{mV}$. Thus, the voltage step to $-10 \mathrm{mV}$ activated only the other $\mathrm{K}^{+}$currents that were present in the cell (Fig. 12Aii). Subtraction of the current remaining after the predepolarization from the total current activated by the prehyperpolarization resulted in isolation of $I_{\mathrm{K}(\mathrm{A})}$ (Fig. 12Aiii). $I_{\mathrm{K}(\mathrm{A}) \text { reached its }}$ peak amplitude in $5 \mathrm{msec}$ and decayed with a time course of 50-80 msec $(n=16)$. The peak amplitude of $I_{\mathrm{K}(\mathrm{A})}$ increased with increasing levels of prehyperpolarization (Fig. 12B), and the relationship between the two was sigmoidal (Fig. 12C).

The presence of $I_{\mathrm{K}(\mathrm{A})}$ was correlated with the pause in firing at the beginning of the current pulse. The peak amplitude of $I_{\mathrm{K}(\mathrm{A})}$ (Fig. 12D, filled circles) and the pause time (Fig. 12D, open circles) showed similar increases as the prehyperpolarization increased in the same cell. The relationship between the pause time and the peak amplitude of $I_{\mathrm{K}(\mathrm{A})}$ was sigmoidal, and the first noticeable pause corresponded to a peak $I_{\mathrm{K}(\mathrm{A})}$ between 2 and $3 \mathrm{nA}$ (Fig. $12 E) . I_{\mathrm{K}(\mathrm{A})}$ was not present in other sustained regular cells with or without adaptation that did not exhibit the pause-build response and was absent in all onset and transiently firing IC neurons and in all cells that exhibited a rebound depolarization (Table 1).

\section{Six distinct firing patterns are observed in the IC}

The stimulation of IC neurons with a combination of depolarizing and hyperpolarizing current resulted in six unique classes of firing patterns, illustrated in Figure 13. Other than the six patterns described above, no other firing pattern combinations were observed in this study.

The sustained-regular firing pattern (Fig. 13A) was observed in $19 \%$ (20 of 104) of IC neurons and consisted of sustained firing with equal interval spikes ("regular") during the depolarizing current pulse, an inwardly rectifying hyperpolarizing response to a negative current pulse, and a sodium-dependent anode-break spike. Equal-interval spiking was observed at all depolarizing current levels below those that produced depolarization block. A Ca-dependent rebound depolarization was not observed after hyperpolarization, and prehyperpolarization had no effect on the onset of firing.

The second firing pattern was the onset response to depolarizing current injection (Fig. 13B), observed in $8 \%$ (9 of 104) of IC neurons. Onset cells also exhibited inward rectification during hyperpolarizing current pulses, as well as anode-break sodium spikes. Onset firing was observed at all of the depolarizing current strengths used. No $\mathrm{Ca}$-dependent rebound depolarization was observed after hyperpolarization, and prehyperpolarization had no effect on the onset of firing.

Pause-build cells comprised 15\% (16 of 104) of IC neurons and were similar to sustained regular cells in their response to depolarizing current, sometimes showing slight adaptation (3 of 16 cells), but differed from the other firing patterns observed in their responses to hyperpolarizing current pulses (Fig. 13C). Negative current pulses that hyperpolarized the cell by more than $\sim 10 \mathrm{mV}$ caused the membrane potential to remain below the resting potential of the cell for up to $250 \mathrm{msec}$ after the end of the hyperpolarizing current, and as a result, the membrane potential 

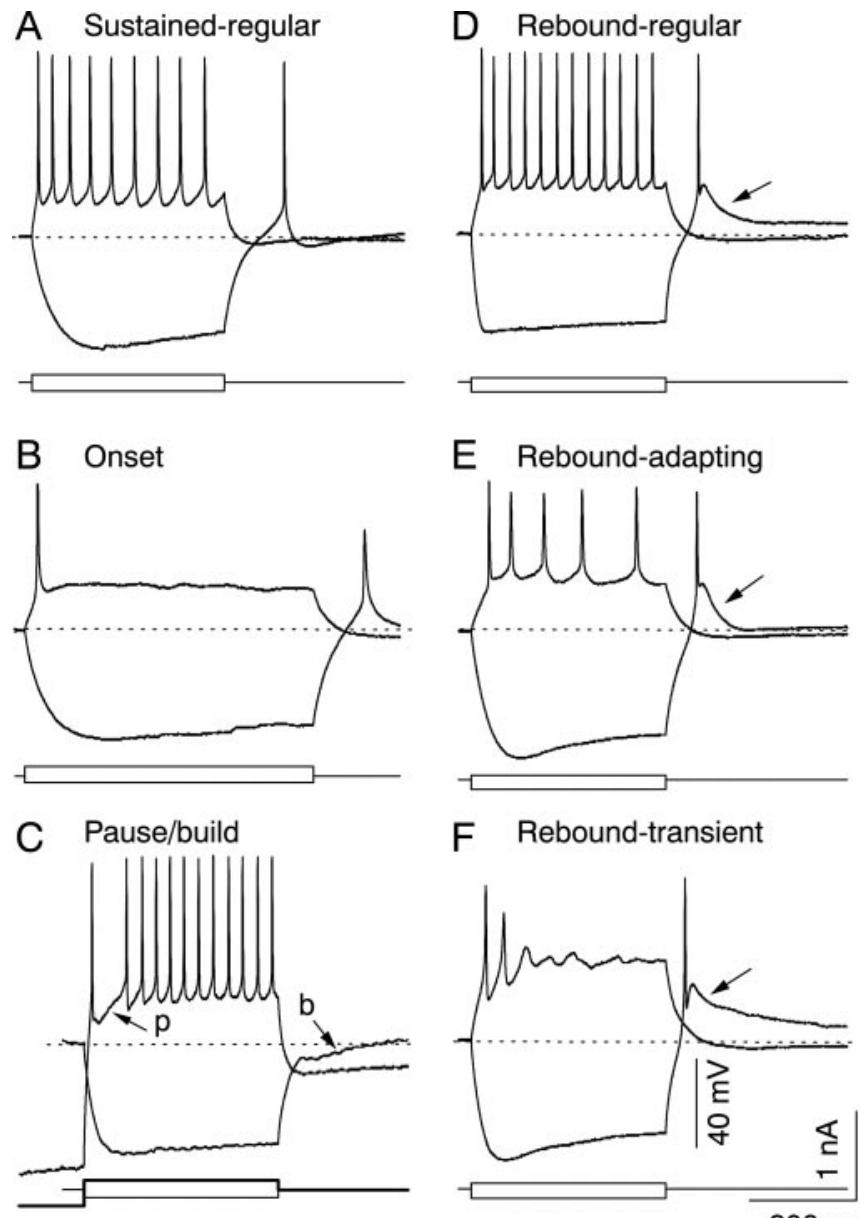

F Rebound-transient

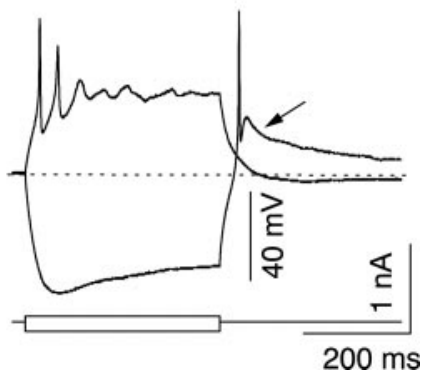

Figure 13. The six firing patterns found in the IC. In each panel, the bottom two traces are the injected depolarizing and hyperpolarizing current pulses, and the top two traces are the voltage responses to each current pulse. Dotted lines indicate resting membrane potentials. A, Sustained-regular firing to depolarization with an anode-break spike and no calcium-rebound following hyperpolarization. $B$, Onset firing to depolarization with an anode-break spike and no calcium-rebound following hyperpolarization. $C$, Sustained firing to depolarization with a pausebuild response after prehyperpolarization and no anode-break spike after hyperpolarization; the thick current trace indicates the current that gave rise to the top voltage trace, and the thinner current trace is the current that gave rise to the bottom trace. The top voltage trace is the response to an initial prehyperpolarization, followed by a depolarizing current pulse, and begins at the prehyperpolarized value of $-90 \mathrm{mV}$. The cell shows a pause in firing $(p)$ after the first spike. The bottom voltage trace is the response to a hyperpolarizing current pulse and shows the buildup response $(b)$ following hyperpolarization. $D$, Sustained-regular firing to depolarization with an anode-break sodium spike and a calcium-rebound following the hyperpolarization. E, Sustained firing with adaptation and calciumsodium rebound activity. $F$, Transient response to depolarization with calcium-sodium rebound activity.

did not reach threshold for the generation of anode-break sodium spikes, which were not observed in any of these cells at hyperpolarizations greater than $10 \mathrm{mV}$. No calcium-dependent rebound depolarizations were observed in pause-build cells. Thus, pausebuild cells differed from sustained-regular cells only in their response to hyperpolarization and to prehyperpolarization, which delayed the onset of firing.

The next three classes of firing patterns, described in the following paragraphs, shared one common feature: a broad calcium-dependent rebound depolarization that followed a hy- perpolarizing current step. In response to depolarizing current pulses, however, cells with a rebound response exhibited three different firing patterns and were therefore divided into three classes. The total number of cells with a calcium-dependent rebound comprised $\sim 57 \%$ (59 of 104 cells) of all IC neurons.

The rebound-regular pattern (Fig. 13D) was observed in $10 \%$ (11 of 104) of IC neurons and was characterized by sustainedregular firing during depolarization, an inwardly rectifying hyperpolarizing response to a negative current pulse, and a sodiumdependent anode-break spike. Prehyperpolarization did not affect the onset of firing.

Cells with a rebound-adapting firing pattern formed the single largest group of cells (25\%, 26 of 104 cells) in the IC (Fig. 13E). These cells exhibited marked adaptation during sustained firing (Peruzzi et al., 2000). Except for the slight adaptation observed in a small fraction of pause-build cells, all of the cells that exhibited marked adaptation during sustained firing also had a calciumdependent rebound depolarization. These cells also showed inward rectification during hyperpolarization and a sodiumdependent anode-break spike. Prehyperpolarization did not affect the onset of firing.

The rebound-transient firing pattern (Fig. 13F) was observed in $21 \%$ (22 of 104) of IC neurons and showed transient firing at all depolarizing current levels, with gradually decreasing spike amplitudes, inward rectification during hyperpolarizing current pulses, and a sodium-dependent anode-break spike. Prehyperpolarization did not affect the onset of firing.

Passive membrane properties of cells with the six firing patterns All IC neurons exhibited both outward rectification to depolarizing currents and inward rectification to hyperpolarizing currents (Fig. 14A-F). The amount of rectification was measured from current-voltage curves obtained from current-clamp recordings in the presence of $1 \mu \mathrm{M}$ TTX. The $I-V$ curves obtained in TTX do not differ significantly from those obtained in normal saline (Peruzzi et al., 2000). Although the amount of outward rectification was relatively constant in all of the cells associated with a certain firing pattern, the amount and time course of the inward rectification varied a great deal. The values of the input resistances, obtained as the slope of the linear portion of the current-voltage curve, and the resting membrane potential of cells with the six firing patterns are shown in Table 1. Superimposition of the $I-V$ curves of cells with the six different firing patterns indicates that they cannot be distinguished on the basis of the amount of outward rectification (Fig. 14G). If the cells are classified according to the values of their input resistances, cells with the six firing patterns fall into three distinct groups: the group containing only onset cells, with the highest input resistance; the group containing rebound-adapting and reboundtransient cells, with a similar input resistance, which is the lowest of the three categories; and the group containing sustainedregular cells, pause-build cells (which exhibit a sustained-regular firing pattern during depolarization), and rebound-regular cells, with similar input resistances that are intermediate between those of the onset and rebound-adapting-transient groups (Fig. 14H). If the cells are categorized according to their resting membrane potentials, cells with the six firing patterns fall into two groups; the first group contains onset cells with the most negative membrane potential $(-60 \mathrm{mV})$, whereas the second group contains the cells with the other five firing patterns, which have membrane potentials that do not differ significantly from each other (Fig. $14 I$ ) but are more depolarized (approximately $-51 \mathrm{mV}$ ) than that 
A Sustained-regular

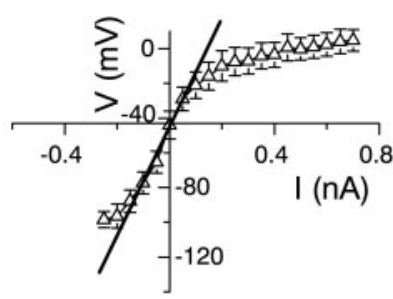

D Rebound-regular

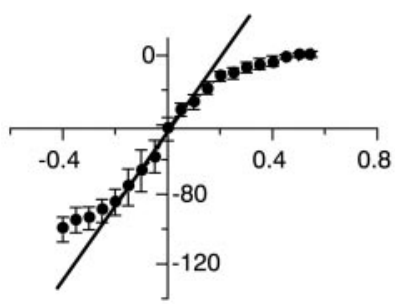

B Onset



E Rebound-adapting

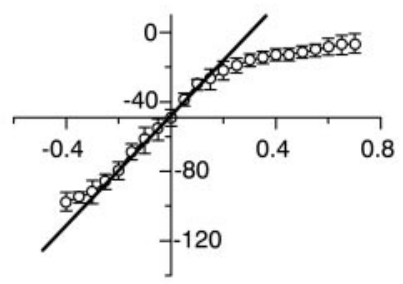

C Pause/build

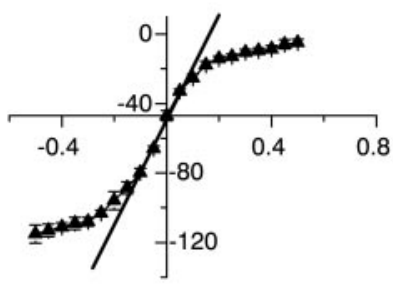

F Transient-rebound

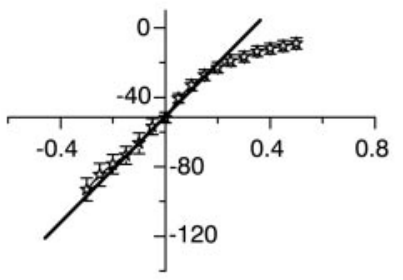

G
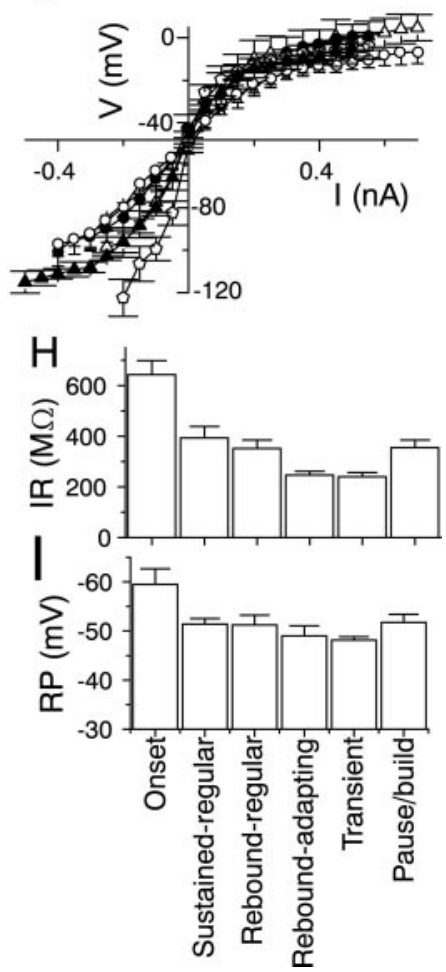

Figure 14. Current-voltage curves, input resistances, and resting potentials in six IC cell types. $A-F$, Current-voltage relationships in sustained-regular, onset, pause-build, rebound-regular, rebound-adapting, and transient-rebound cells. Input resistance was measured by a linear fit to the slope of the curve near zero. $G$, Comparison of $I-V$ curves shows differences to hyperpolarizing currents. $H$, Comparison of input resistance (IR) by cell type. $I$, Comparison of resting potential $(R P)$ by cell type. The number of cells for each cell type is given in Table 1.

of onset cells. Therefore, although six, clearly distinguishable firing patterns are observed in the IC, overlapping subsets of these firing patterns share a combination of input resistance and resting potential values. Thus, IC neurons cannot be unequivocally distinguished by their passive membrane properties alone. This fact is not surprising given that these two cellular features are determined by a combination of several factors, such as cell size and resting potassium levels, which are common to most cells in the CNS.

The six firing patterns are associated with unique combinations of $\mathrm{K}^{+}$- and $\mathrm{Ca}^{2+}$-dependent currents

Unlike the ambiguous distribution of input resistance and resting potential values, each of the six firing patterns illustrated in Figure 13 is associated with a distinct $\mathrm{K}^{+}$current, listed in Table 1. The types of $\mathrm{K}^{+}$currents found in each of the cells are as follows. (1) Sustained-regular cells contain $\mathrm{K}^{+}$currents that are blocked primarily by $2 \mathrm{~mm} 4-\mathrm{AP}$ and $5 \mathrm{~mm}$ TEA-Cl, suggesting that they flow mainly through delayed rectifier $\mathrm{K}^{+}$channels. These cells lack calcium-dependent $\mathrm{K}^{+}$currents, high-threshold, TEA-sensitive $\mathrm{K}^{+}$currents, transient A-type $\mathrm{K}^{+}$currents, or a calcium-dependent rebound. (2) Onset cells have a unique highthreshold TEA-sensitive $\mathrm{K}^{+}$current, as well as a low-threshold $\mathrm{K}^{+}$current, but lack calcium-dependent $\mathrm{K}^{+}$currents or a calcium-dependent rebound. (3) Pause-build cells have an A-current but no high-threshold TEA-sensitive $\mathrm{K}^{+}$currents or a calcium-dependent rebound. A few pause-build cells that exhibit slight adaptation (18\%) have a small apamin-sensitive current that makes up $\sim 9 \%$ of the total $\mathrm{K}^{+}$current. (4) Rebound-regular cells lack a calcium-dependent $\mathrm{K}^{+}$current, high-threshold TEA- sensitive $\mathrm{K}^{+}$currents, and A-type $\mathrm{K}^{+}$currents. Similar to sustained-regular cells, rebound-regular cells contain delayed rectifier $\mathrm{K}^{+}$currents sensitive to 2 mM 4-AP. However, these cells do have calcium-dependent rebound depolarizations and differ in this respect from sustained-regular cells. (5) Rebound-adapting cells have both an apamin-sensitive calcium-dependent $\mathrm{K}^{+}$current and a calcium-dependent rebound depolarization. However, they lack a high-threshold TEA-sensitive $\mathrm{K}^{+}$current and an A-type $\mathrm{K}^{+}$current and show little sensitivity to charybdotoxin. (6) Transient-rebound cells have a charybdotoxin-sensitive calcium-dependent $\mathrm{K}^{+}$current and a calcium-dependent rebound, but lack apamin-sensitivity, and do not contain a highthreshold $\mathrm{K}^{+}$current or an A-current.

Thus, although $\mathrm{K}^{+}$currents sensitive to the nonspecific $\mathrm{K}^{+}$ channel blocker 4-AP (2 mM) are present in all of the cells in the $\mathrm{IC}$, each of the six different firing patterns is associated with an additional unique combination of $\mathrm{K}^{+}$currents that gives rise to one or more aspects of its firing.

\section{The IC contains six physiologically distinct cell types}

When IC neurons are stimulated with a combination of depolarizing and hyperpolarizing current steps, they exhibit six distinct firing patterns. Each of these firing patterns is associated with a unique $\mathrm{K}^{+}$current. Other characteristics of IC neurons, such as resting membrane potential, input resistance, action potential shape, and firing pattern in response to either depolarizing or hyperpolarizing current (but not both), do not have a unique association with each other (Table 1), indicating that these parameters cannot be used to categorize IC neurons. However, once the cells are divided on the basis of their firing patterns to 
combined depolarizing and hyperpolarizing stimuli, and the types of $\mathrm{K}^{+}$currents associated with each, it is apparent that no two of these classes share an entire set of the cellular parameters tested in this study. Therefore, there are six physiologically distinct cell types in the IC, each of which can be recognized by the firing pattern obtained in response to a combination of depolarizing and hyperpolarizing stimuli.

\section{DISCUSSION}

Our results suggest that there are six intrinsic, physiologically defined cell types in the IC of the rat. These physiological classes are not correlated with the morphologically defined disk-shaped and stellate cells described in the rat IC by Malmierca et al. (1993) but may be correlated with other characteristics not yet defined (Peruzzi et al., 2000). The present classification scheme differs from ones based on responses to sound (Le Beau et al., 1996; Rees et al., 1997), in which the "chopper," "pauser," or "onset" behavior of a neuron is likely to result from the interaction of its intrinsic properties with its synaptic inputs. Our results indicate that cells with onset, pauser, etc., firing patterns are intrinsically present in the IC but do not exclude the possibility that these firing patterns can also be evoked by synaptic stimulation.

The convergence of excitatory and inhibitory synaptic inputs from lower brainstem nuclei upon a single IC neuron produces temporally summed depolarizations or hyperpolarizations, and the duration and amplitude of the envelope of the stimulus is not unlike the current injected into IC neurons in the present currentclamp experiments. The firing patterns exhibited by IC neurons suggest that there would be both similarities and differences among them in their responses to excitatory or inhibitory inputs. Furthermore, some cells are likely to show little or no plasticity and behave as simple relays of temporal and intensity information, whereas others are likely to transform their inputs.

The sustained-regular firing pattern is determined by delayedrectifying 4-AP-sensitive $\mathrm{K}^{+}$currents that cause sustained firing during an excitatory stimulus, and because they fire throughout the stimulus, sustained-regular cells will provide information about the duration of the input signal. These cells are also likely to have linear rate-level functions, and our data show that this linearity is derived from the linear increase in $\mathrm{K}^{+}$current magnitude with voltage. Because these cells maintain their firing pattern when prehyperpolarized, synaptic inhibition that precedes excitation is unlikely to alter the linearity of the rate-level function.

The low-threshold and high-threshold $\mathrm{K}^{+}$currents present in onset cells may both contribute to temporal processing. These currents will rapidly repolarize the cell after both single and summated excitatory synaptic currents, so that onset firing is not likely to change with stimulus duration and intensity. Thus, onset cells cannot code stimulus duration and intensity. For the same reason, however, they are better than sustained cells at temporal coding and phase-locking. The low-threshold $\mathrm{K}^{+}$current is active near rest and is likely to be responsible for the relatively negative resting potential of onset cells. Because it inactivates little during a prolonged depolarization, it is suited to rapidly repolarize the cell, resulting in a short refractory period after an action potential and a rapid decay of synaptic currents. In contrast, the highthreshold $\mathrm{K}^{+}$current activates at potentials more positive than $-10 \mathrm{mV}$ and may be a safety mechanism for onset cells. Even with large, temporally summated synaptic potentials, activation of the high-threshold current would repolarize the membrane rap- idly and the onset cell would retain its ability to follow stimuli at high frequencies $(\sim 300 \mathrm{~Hz})$ (Peruzzi et al., 2000). Thus, as suggested for MNTB neurons (Wang et al., 1998), the low- and high-threshold $\mathrm{K}^{+}$currents may act together to set the highfrequency limit at which onset cells in the IC can follow stimuli.

Pause-build neurons exhibit sustained, regular firing during depolarizing currents and, like sustained-regular cells, are likely to code intensity well. Unlike sustained-regular cells, however, the A-current in pause-build cells makes them uniquely equipped to code for two time-dependent phenomena: the time interval between successive excitatory inputs to the cell, and the pairing of excitation with inhibition.

In pause-build cells, sustained firing during a prolonged excitatory stimulus is followed by an intrinsic afterhyperpolarization of the cell membrane that is sufficient to remove the inactivation of the A-current. If a second excitatory stimulus arrives during this afterhyperpolarization, it would activate the A-current, resulting in a pause in firing. Because the magnitude of the A-current is directly proportional to the magnitude and duration of the afterhyperpolarization, the pause time (or delay in firing onset) would be directly proportional to the time interval between the first and second stimulus, as demonstrated for fusiform cells in the cochlear nucleus (Rhode et al., 1983). Thus, the pause time would act as an inverse code for stimulus interval; long delays or pauses in firing onset during the second excitatory stimulus imply closely spaced stimuli. Our results in the IC indicate that coding for time interval is possible only for $\sim 80-100$ msec after the response to the first stimulus, because, after this time, the A-current would have decayed to zero, and no delay will be observed in firing onset to the second of two stimuli. Thus, pause-build cells would respond to changing stimulus intervals only for stimulus intervals $<100 \mathrm{msec}$.

Pause-build cells are also suited to register the pairing between excitatory and inhibitory synaptic inputs to the cell (EPSPs and IPSPs). IPSPs, either single or summated, can serve to remove the inactivation of the A-current; thus, the response of pause-build cells to EPSPs that are preceded by IPSPs will depend on the magnitude of the IPSP, as well as the interval between the IPSP and EPSP, for the same reason as outlined for the phenomenon of afterhyperpolarization. Again, because of the 80-100 msec decay time of the A-current, EPSPs that lag IPSPs by $>100 \mathrm{msec}$ will be treated as being independent of the preceding inhibition. IPSPs frequently lead EPSPs in the IC $(\mathrm{Ku}-$ wada et al., 1997); thus, the role of pause-build cells may be directly concerned with the timing of inhibition and excitation, and a pause-build response that is evoked with the first excitatory stimulus would suggest the presence of preceding synaptic inhibition.

Rebound neurons may be significantly better than other neurons in the IC at synchronizing their offset responses to timelocked inhibitory inputs. Rebound depolarization increases the probability of a sodium-dependent anode-break spike, which occurs at smaller hyperpolarizations and with shorter latencies at offset than in cells without the rebound. Kuwada and Batra (1999) suggest that an inhibitory rebound mechanism is sufficient to encode ongoing envelopes in complex sounds with high fidelity, and this is likely to be the role played by rebound neurons in the IC. The calcium dependence of the rebound suggests that the synchrony of the off response is activity-dependent and can be altered by the magnitude of the hyperpolarization.

Like sustained-regular cells, rebound-regular cells have delayed-rectifying $\mathrm{K}^{+}$currents and would be good intensity cod- 
ers with linear rate-level functions, with the additional capability to provide a high degree of synchrony at the offset of inhibition. In sustained-adapting rebound cells, the interspike interval is maintained by an apamin-sensitive calcium-dependent $I_{\mathrm{K}(\mathrm{Ca})}$. Blocking this current by apamin affects the firing pattern, abolishing sustained firing, only after the first 150-200 msec after the onset of the stimulus. The firing pattern of these neurons is therefore dependent on stimulus duration, and they adapt to stimuli longer than $200 \mathrm{msec}$, filtering out information after that time. Transient-rebound cells contain a CTX-sensitive $I_{\mathrm{K}}$, which has calcium-sensitive and calcium-insensitive components. This current affects the afterhyperpolarization that follows a single action potential and causes transient firing in a cell capable of sustained behavior.

Cai et al. (1998) suggested that an $I_{\mathrm{K}(\mathrm{Ca})}$ with an inactivation time constant of $500 \mathrm{msec}$ may underlie the afterhyperpolarization observed in IC neurons, and therefore, their sensitivity to interaural phase modulation. The apamin-sensitive $I_{\mathrm{K}(\mathrm{Ca})}$ in sustainedadapting cells is slow enough to comply with the 500 msec decay time course; however, it does not underlie the afterhyperpolarization that follows either a single action potential or sustained firing in these cells. The voltage-dependent charybdotoxin-sensitive $I_{\mathrm{K}}$ present in transiently firing cells also does not fulfill the criteria necessary for interaural phase modulation. Although this current underlies the afterhyperpolarization that follows a single action potential, it does not affect that which follows sustained firing, and it inactivates too rapidly (time constant of $50 \mathrm{msec}$ ). Thus, it seems likely that currents other than apamin and charybdotoxin-sensitive $\mathrm{Ca}^{2+}$-activated potassium currents may underlie the sensitivity of IC neurons to interaural phase modulations.

Our results suggest that the greater part of the IC is capable of exhibiting activity-dependent modification of the incoming sound signal, whereas a smaller part of it transfers the signal unmodified to its target. Rebound and pause-build cells, whose firing patterns are modified by inhibition, together make up $72 \%$ of IC neurons; inhibition therefore plays a predominant role in shaping the response of the IC to sound. Adapting and transient cells comprise $46 \%$ of IC neurons; thus, approximately half of the IC is geared to modification during excitatory stimuli. On the other hand, because sustained-regular and onset cells together comprise only $28 \%$ of IC neurons, less than one-third of the IC can serve as a relay of the intensity and temporal information in the sound signal. It is likely that disparate pathways exist in the IC for the unmodified transference and activity-dependent modification of the incoming sound signal.

\section{REFERENCES}

Brew HM, Forsythe ID (1995) Two voltage-dependent $\mathrm{K}^{+}$conductances with complementary functions in postsynaptic integration at a central auditory synapse. J Neurosci 15:8011-8022.

Cai H, Carney LH, Colburn HS (1998) A model for binaural response properties of inferior colliculus neurons. II. A model with interaural time difference-sensitive excitatory and inhibitory inputs and an adaptation mechanism. J Acoust Soc Am 103:494-506.

Chandy GK, Guttman GA (1995) Voltage-gated potassium channel genes. In: Handbook of receptors and channels: ligand- and voltagegated ion channels (North A, ed), pp 1-71. Boca Raton, FL: CRC.

Connor JA, Stevens CF (1971a) Voltage clamp studies of a transient outward membrane current in gastropod neural somata. J Physiol (Lond) 213:21-30.

Connor JA, Stevens CF (1971b) Prediction of repetitive firing behavior from voltage clamp data on an isolated neurone soma. J Physiol (Lond) 213:31-53.

Forsythe ID, Barnes-Davies M (1993) The binaural auditory pathway: membrane currents limiting multiple action potential generation in the rat medial nucleus of the trapezoid body. Proc R Soc Lond B Biol Sci 251:143-150.

Grissmer S, Nguyen AN, Aiyer J, Hanson DC, Mather RJ, Gutman GA, Karmilowicz MJ, Auperin DD, Chandy KG (1994) Pharmacological characterization of five cloned voltage-gated $\mathrm{K}^{+}$channels, types Kv1.1, $1.2,1.3,1.5$, and 3.1 , stably expressed in mammalian cell lines. Mol Pharmacol 45:1227-1234.

Guttman R, Barnhill R (1970) Oscillation and repetitive firing in squid axons. Comparison of experiments with computations. J Gen Physiol 55:104-118.

Hamill OP, Marty A, Neher E, Sakmann B, Sigworth FJ (1981) Improved patch-clamp techniques for high-resolution current recording from cells and cell-free membrane patches. Pflügers Arch 391:85-100.

Hartmann HA, Kirsch GE, Drewe JA, Taglialatela M, Joho R, Brown AM (1991) Exchange of conduction pathways between two related $\mathrm{K}^{+}$channels. Science 251:942-944.

Hodgkin AL, Huxley AF (1952) A quantitative description of membrane current and its application to conduction and excitation in nerve. J Physiol (Lond) 117:500-544.

Hughues M, Romey G, Duval D, Vincent JP, Lazdunski M (1982) Apamin as a selective blocker of the $\mathrm{Ca}^{++}$-dependent $\mathrm{K}^{+}$channel in neuroblastoma cells: voltage-clamp and biochemical characterization of the toxin receptor. Proc Natl Acad Sci USA 79:1308-1312.

Kanold PO, Manis PB (1999) Transient $\mathrm{K}^{+}$currents regulate the discharge patterns of dorsal cochlear nucleus pyramidal cells. J Neurosci 19:2195-2208.

Kim DO, Ghoshal S, Khant SL, Parham K (1994) A computational model with ionic conductances for the fusiform cell of the dorsal cochlear nucleus. J Acoust Soc Am 96:1501-1514.

Kuwada S, Batra R (1999) Coding of sound envelopes by inhibitory rebound in neurons of the superior olivary complex in the unanesthetized rabbit. J Neurosci 19:2273-2287.

Kuwada S, Yin TC, Syka J, Buunen TJ, Wickesberg RE (1984) Binaural interaction in low frequency neurons in inferior colliculus of the cat. IV. Comparison of monaural and binaural response properties. J Neurophysiol 51:1306-1325.

Kuwada S, Batra R, Yin TCT, Oliver D, Haberly LB, Stanford TR (1997) Intracellular recordings in response to monaural and binaural stimulation of neurons in the inferior colliculus of the cat. J Neurosci 17:7565-7581.

Lang EJ, Sugihara I, Llinas R (1997) Differential roles of apamin- and charybdotoxin-sensitive $\mathrm{K}^{+}$conductances in the generation of inferior olive rhythmicity in vivo. J Neurosci 17:2825-2838.

Le Beau FEN, Rees A, Malmierca MS (1996) Contribution of GABAand glycine-mediated inhibition to the monaural temporal response properties of neurons in the inferior colliculus. J Neurophysiol 75:902-919.

Luneau CJ, Williams JB, Marshall J, Levitan ES, Oliva C, Smith JS, Antanavage J, Folander K, Stein RB, Swanson R, Kaczmarek LK, Buhrow SA (1991) Alternative splicing contributes to $\mathrm{K}^{+}$channel diversity in the mammalian central nervous system. Proc Natl Acad Sci USA 88:3932-3936.

Malmierca MS, Blackstad TW, Osen KK, Karaguelle T, Molowny RL (1993) The central nucleus of the inferior colliculus in rat: a Golgi and computer reconstruction study of neuronal and laminar structure. J Comp Neurol 333:1-27

Manis PB, Marx SO (1991) Outward currents in isolated ventral cochlear nucleus neurons J Neurosci 11:2865-2880.

McAlpine D, Jiang D, Shackleton TM, Palmer AR (2000) Responses of neurons in the inferior colliculus to dynamic interaural phase cues: evidence for a mechanism of binaural adaptation. J Neurophysiol 83:1356-1365.

Miller CE, Moczydlowski E, Latorre R, Phillips M (1985) Charybdotoxin, a protein inhibitor of single $\mathrm{Ca}$-activated $\mathrm{K}$ channels from mammalian skeletal muscle. Nature 313:316-318.

Neher E (1971) Two fast transient current components during voltage clamp on snail neurons. J Gen Physiol 58:36-53.

Peruzzi D, Sivaramakrishnan S, Oliver DL (2000) Identification of cell types in brain slices of the inferior colliculus. Neuroscience 101:403-416.

Rees A, Sarbaz A, Malmierca MS, Le Beau FEN (1997) Regularity of firing of neurons in the inferior colliculus. J Neurophysiol 77:2945-2965.

Reyes AD, Rubel EW, Spain WJ (1994) Membrane properties underlying the firing of neurons in the avian cochlear nucleus. $J$ Neurosci 14:5352-5364.

Rhode WS, Smith PH, Oertel D (1983) Physiological response properties of cells labeled intracellularly with horseradish peroxidase in cat dorsal cochlear nucleus. J Comp Neurol 213:426-447.

Sah P (1996) Calcium-activated K currents in neurones: types, physiological roles and modulation. Trends Neurosci 19:150-154.

Sah P, Isaacson JS (1995) Channels underlying the slow afterhyperpolarization in hippocampal pyramidal neurons: neurotransmitters modulate the open probability. Neuron 15:435-441. 
Sakmann B, Neher E (1984) Patch clamp techniques for studying ionic channels in excitable membranes. Annu Rev Physiol 46:455-472.

Saldana E, Merchan MA (1992) Intrinsic and commissural connections of the rat inferior colliculus. J Comp Neurol 319:417-437.

Sivaramakrishnan S, Laurent G (1995) Pharmacological characterization of presynaptic $\mathrm{Ca}^{2+}$ currents underlying glutamatergic transmission in the avian auditory brainstem. J Neurosci 15:6576-6585.

Sivaramakrishnan S, Oliver DL (1998) Ionic mechanisms underlying firing patterns in rat inferior colliculus. Soc Neurosci Abstr 24:1636.

Smith PH (1992) Anatomy and physiology of multipolar cells in the rat inferior collicular cortex using the in vitro brain slice technique. J Neurosci 12:3700-3715.
Wagner T (1994) Intrinsic properties of identified neurones in the central nucleus of mouse inferior colliculus. NeuroReport 6:89-93.

Wang GY, Olshausen BA, Chalupa LM (1999) Differential effects of apamin- and charybdotoxin-sensitive $\mathrm{K}$ conductances on spontaneous discharge patterns of developing retinal ganglion cells. J Neurosci 19:2609-2618.

Wang LY, Gan L, Forsythe ID, Kaczmarek LK (1998) Contribution of the Kv3.1 K ${ }^{+}$channel to high-frequency firing in mouse auditory neurons. J Physiol (Lond) 509:183-194.

Zhang S, Trussell LO (1994) A characterization of excitatory postsynaptic potentials in the avian nucleus magnocellularis. J Neurophysiol 72:705-718 